\title{
Electrospun Nanosystems Based on PHBV and ZnO for Ecological Food Packaging
}

\author{
Maria Râpă ${ }^{1}$, Maria Stefan ${ }^{2, *}$, Paula Adriana Popa ${ }^{2} \oplus$, Dana Toloman ${ }^{2}$, Cristian Leostean ${ }^{2}$, Gheorghe Borodi ${ }^{2}$,

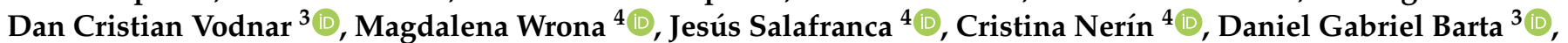 \\ Maria Suciu $^{2}{ }^{\mathbb{D}}$, Cristian Predescu ${ }^{1}$ and Ecaterina Matei ${ }^{1, *}$
}

1 Faculty of Materials Science and Engineering, University Politehnica of Bucharest, 313 Splaiul Independentei, 060042 Bucharest, Romania; rapa_m2002@yahoo.com (M.R.); cpredescu56@yahoo.com (C.P.)

2 National Institute for Research and Development of Isotopic and Molecular Technologies, Donat Street 67-103, 400293 Cluj-Napoca, Romania; popa@itim-cj.ro (P.A.P.); dana.toloman@itim-cj.ro (D.T.); cleostean@itim-cj.ro (C.L.); gheorghe.borodi@itim-cj.ro (G.B.); maria.suciu@itim-cj.ro (M.S.)

3 Department of Food Science, University of Agricultural Sciences and Veterinary Medicine, 3-5 Calea Manastur, 400372 Cluj-Napoca, Romania; dan.vodnar@usamvcluj.ro (D.C.V.); gabriel.barta@usamvcluj.ro (D.G.B.)

4 Department of Analytical Chemistry, Aragon Institute of Engineering Research I3A, EINA-University of Zaragoza, Torres Quevedo Building, María de Luna 3, 50018 Zaragoza, Spain; magdalenka.wrona@gmail.com (M.W.); fjsl@unizar.es (J.S.); cnerin@unizar.es (C.N.)

* Correspondence: mstefan@itim-cj.ro (M.S.); ecaterinamatei@gmail.com (E.M.)

check for updates

Citation: Râpă, M.; Stefan, M.; Popa, P.A.; Toloman, D.; Leostean, C.; Borodi, G.; Vodnar, D.C.; Wrona, M.; Salafranca, J.; Nerín, C.; et al.

Electrospun Nanosystems Based on $\mathrm{PHBV}$ and $\mathrm{ZnO}$ for Ecological Food Packaging. Polymers 2021, 13, 2123. https://doi.org/10.3390/ polym13132123

Academic Editor: Alexey Iordanskii

Received: 8 May 2021

Accepted: 25 June 2021

Published: 28 June 2021

Publisher's Note: MDPI stays neutral with regard to jurisdictional claims in published maps and institutional affiliations.

Copyright: (c) 2021 by the authors. Licensee MDPI, Basel, Switzerland. This article is an open access article distributed under the terms and conditions of the Creative Commons Attribution (CC BY) license (https:// creativecommons.org/licenses/by/ $4.0 /)$.
Abstract: The electrospun nanosystems containing poly(3-hydroxybutyrate-co-3-hydroxyvalerate) (PHBV) and $1 \mathrm{wt} \%$ Fe doped $\mathrm{ZnO}$ nanoparticles (NPs) (with the content of dopant in the range of $0-1 \mathrm{wt} \% \mathrm{Fe}$ ) deposited onto polylactic acid (PLA) film were prepared for food packaging application. They were investigated by scanning electron microscopy (SEM), energy dispersive X-ray (EDX), Fourier transform infrared spectroscopy (FT-IR), X-ray diffraction (XRD), antimicrobial analysis, and X-ray photoelectron spectrometry (XPS) techniques. Migration studies conducted in acetic acid 3\% $(w t / w t)$ and ethanol 10\% (v/v) food simulants as well as by the use of treated ashes with $3 \% \mathrm{HNO}_{3}$ solution reveal that the migration of $\mathrm{Zn}$ and Fe falls into the specific limits imposed by the legislation in force. Results indicated that the PLA/PHBV/ZnO:Fex electrospun nanosystems exhibit excellent antibacterial activity against the Pseudomonas aeruginosa (ATCC-27853) due to the generation of a larger amount of perhydroxyl $(\cdot \mathrm{OOH})$ radicals as assessed using electron paramagnetic resonance (EPR) spectroscopy coupled with a spin trapping method.

Keywords: PHBV; Fe-doped ZnO nanoparticles; electrospinning; PLA; migration; antimicrobial; compositional analysis; food packaging

\section{Introduction}

Food packaging materials are essential in our economy and daily lives. The growing consumption of single-use food packaging includes trays, cups, bottles, bags, lids, straws, and cutlery, thus increasing the amount of plastic waste generated each year. Manufactured food packaging from conventional plastics like polyethylene (PE), polystyrene (PS), polypropylene (PP), and polyethylene terephthalate (PET) are a source of unintentionally produced microplastics (plastic fragments lower than $5 \mathrm{~mm}$ in size), generating a toxic effect both for the natural environment and human health [1]. Recent studies reported microplastics in air, drinking water, consumed milk, and other beverages [2]. A study conducted by Kedzierski et al. [3] reported that one person could be ingesting $1.4 \mathrm{mg}$ of extruded polystyrene (XPS) microparticles per day.

Innovative solutions for friendly food packaging prove the use of alternative feedstocks for plastic production compared with non-renewable plastics able to be recycled, 
providing antibacterial activity for a long time to prolong the shelf life of stored food $[4,5]$, consumer safety, and adequate mechanical and thermal properties.

In recent years, serious efforts have been made to develop sustainable food packaging materials to ensure full food quality. Biopolymers obtained from different natural resources are considered an attractive alternative to non-biodegradable petroleum-based plastics, as they are renewable, environmentally friendly, and biodegradable. Among the biodegradable polymers used to obtain food packaging, the best known are polylactic acid (PLA) and polyhydroxyalkanoates (PHAs). The use of PLA for food packaging is limited because it has low mechanical and thermal properties, low ductility, and its oxygen barrier properties are quite low compared to conventional polymers. These drawbacks are overcome by the introduction of plasticizers in the PLA matrix [6-8]. Polyhydroxybutyrate (PHB) and its copolymer, poly(3-hydroxybutyrate-co-3-hydroxyvalerate) (PHBV) are the two most representative natural polyesters of microbial origin belonging to the PHA family. Although PHB shows rigidity similar to PP [9], its sensorial results on the food were positive. The nanocomposites based on PHB containing graphene nanoplatelets (Gr-NPs) in a concentration of $0-1.3 \mathrm{wt} \%$ prepared by a casting solution [9] and silver in a single step approach [10], in addition to blends with PLA [11], have been investigated for the design of food packaging. PHVB blended with natural rubber (NR) by melt processing [12], plasticized with PEG and incorporating $13 \mathrm{wt} . \%$ of active compounds (carvacrol-CA, eugenol-EU) obtained by spraying [13], or loaded with Salmonella Enteritidis bacteriophage Felix O1, for potential use as an anti-Salmonella agent [14], indicate their potential commercial applications in safe food packaging. Overall, migration tests for the PLA/PHB (85:15) performed in non-polar and polar food simulants showed that the total amount of non-volatile substances are in the accepted legislative limit. It was found that the mechanical properties of PLA/PHB blends were enhanced by addition of the plasticizer, and the total amount of non-volatile substances migrated in contact with non-polar and polar food simulant are in the accepted legislative limit [15]. PLA/PHBV blends were used in food packaging [16], medical devices [17], and wastewater treatment [18]. The incorporation of $0.25 \mathrm{wt} \%$ nanocrystalline cellulose improves the morphology, mechanical, and barrier properties of PLA/PHBV composites obtained by the solvent casting method [18].

Developing antimicrobial packaging materials may prevent or delay food spoilage on the surface of the food [19-26]. An approach to the problem of microbial adhesion involves pretreating the sensitive surface with an antimicrobial agent. When impregnated with biocides or antibiotics, some materials can resist bacterial colonization as long as antibacterial agents are released from their surfaces [27]. The European Union has established that the chemicals that could migrate into the food from food packaging should not exceed $60 \mathrm{mg} \mathrm{kg}^{-1}$ of food, or $10 \mathrm{mg} \mathrm{dm}^{-2}$ relative to the surface area [28]. Many studies have reported the use of inorganic nanoparticles, such as silver $(\mathrm{Ag})[29,30]$, iron oxide $\left(\mathrm{Fe}_{3} \mathrm{O}_{4}\right)$ [31], copper oxide (CuO) [32], and zinc oxide ( $\left.\mathrm{ZnO}\right)$ [33], both as reinforcing agents for improving the mechanical properties of polymeric biocomposites as well as for adding functional properties, such as antimicrobial activity. Methods for incorporating nanoparticles, chemical composition, crystallinity, size, and shape can be controlled in order to adjust the properties of the packaging materials [34,35]. However, nanoparticles can migrate to packaged foods [36-38]. ZnO nanoparticles (NPs) have high absorption in the UV field and therefore are used for various applications such as photocatalysis [39], medicine, cosmetics, medical dressings [40,41], optoelectronic and medical imaging devices [42], antibacterial coatings [43], and food packaging [44-47]. In addition, $\mathrm{ZnO}$ nanoparticles are considered non-toxic and recognized by the FDA as safe substances, and recent studies have reported that they do not cause DNA damage to human cells [48]. According to the scientific state of the art, it is well known that the synthesis methods of ZnO NPs influence their morphology and properties $[49,50]$ and their doping with metal ions contributes to the improvement of its properties, such as the increase of lattice defects, the generation of electron-hole pairs, and the shift of the spectral response to the visible range of spectra [51,52]. Therefore, $\mathrm{ZnO}$ NPs can be synthesized by precipitation [53], the hydrothermal method [54], electrochemi- 
cal decomposition [55], the sono-chemical method [56], and sol-gel [57]. The precipitation method has some advantages over other physical or chemical synthesis methods, among which the need for a simple and unsophisticated apparatus and the possibility of obtaining large-scale nanoparticles with controlled shape and size. Moreover, this method allows rigorous control of nuclear and particle growth in solution [52,58,59]. $\mathrm{ZnO}$ doping with $\mathrm{Fe}$ ions effectively modifies the structural and morphological properties, as well as the electrical, optical, and magnetic properties, which can give these nanomaterials applications in different fields $[60,61]$. Nanocomposite films based on PLA or poly(3-hydroxybutyrateco-3-hydroxyvalerate (PHBV) and ZnO NPs manufactured by melt compounding, with multifunctional properties (water vapor barrier, antimicrobial activity), have been reported, which recommends them for use as food packaging [43,62-64]. The difficulty of incorporating the inorganic antimicrobial agent in polymeric matrices by the melting or casting processes consists of its agglomeration, which need to incorporate a huge amount of antimicrobial agents, leading to toxicity increasing the migration in food simulants and deterioration of the properties in the food packaging [64,65].

Electrospinning is a versatile technique, applied to polymers to obtain nanofibers with functional properties. The principle of operation is to create a high voltage electric field between the polymer solution and the metal collector on which it is deposited in the form of fibers. Nanofibers obtained by electrospinning have improved physicochemical properties compared to fibers at the macro level and are therefore increasingly being researched for use in new food packaging systems. The advantage of nanofibers resides in the large ratio between surface area and volume, of 1-3 orders of magnitude higher compared to thin films made of the same material [66]. In addition, the electrospinning process is non-invasive and does not require the use of chemicals or high temperatures to obtain fibers. Electrospinning technology can use synthetic or natural polymer solutions, polymer mixtures, nanoparticles, and antimicrobial agents, which have a viscosity in solution suitable for producing nanofibers. For example, poly(vinyl alcohol) (PVA)-based nanofibers containing varying amounts of Fe-doped $\mathrm{ZnO}$ nanoparticles with antibacterial properties [31], ethyl cellulose/gelatin, and $\mathrm{ZnO}$ compositions with excellent hydrophobicity, water stability, and antimicrobial activity suitable for potential use in food packaging [47], chitosan nanofibers containing $\mathrm{ZnO}$ for medical applications [40], PHBV and ZnO NPs electrospun composite fibers for optoelectronic devices, and the biomedical imaging [42] have been reported. However, the investigated electrospun nanosystems based on PHBV and $\mathrm{ZnO}$ and deposited onto PLA film were not reported in terms of their morphology, migration, and antimicrobial characteristics proved by ROS generation. Antimicrobial food packaging that is sustainable, uses ecological technology for their fabrication, and does not release particles above the specific limit are required on the market.

The novelty of this paper consists of the incorporation of $\mathrm{ZnO}$ :Fe metal oxide nanoparticles/antimicrobial agents in PHBV through electrospinning/electrospray technology and collecting the produced nanofibers onto the PLA film. The objectives of this paper were: (i) to incorporate Fe-doped $\mathrm{ZnO}$ nanoparticles in PHBV and to coat the PLA film with a maximum thickness of $0.1 \mathrm{~mm}$ by electrospinning; (ii) to investigate the structural (FT-IR, XRD), morphology (SEM), compositional analysis (XPS, EDX), and migration in three food simulants as well as antimicrobial properties in order to assess their potential for food packaging.

\section{Materials and Methods}

\subsection{Materials}

PLA pellets Ingeo ${ }^{\circledR}$ Biopolymer 4032D type (NatureWorks, Minnetonka, MN, USA) containing renewable resources is characterized by excellent optical, gas, and oil barrier properties. It is approved for use in food packaging applications. In this study, PLA was used as flexible films with the role of a coating substrate for electrospun nanofibers. PHBV pellets containing $12 \mathrm{~mol} \%$ polyhydroxyvalerate (GoodFellow, Huntingdon, UK) show similar properties to polyolefins, a density of $1.25 \mathrm{~g} / \mathrm{cm}^{3}$, an elongation at break of $35 \%$, 
and tensile strength at a break of $23 \mathrm{MPa}$. PLA is very hygroscopic and might retain moisture from the air, leading to degradation of macromolecular chains, reducing product viscosity and resistance. Therefore, prior to use, the PLA and PHVB pellets were dried in an oven with air circulation at a temperature of $50^{\circ} \mathrm{C}$ for $24 \mathrm{~h}$ (moisture content $<200 \mathrm{ppm}$ ). Dichloromethane and ethyl alcohol solvents and food simulants ( $3 \%$ acetic acid $(w / v), 10 \%$ ethyl alcohol $(v / v)$ ), and $3 \% \mathrm{HNO}_{3}$ solution were of an analytical grade.

Materials and reagents used for the preparation of $\mathrm{ZnO}$ NPs were: zinc nitrate$\mathrm{Zn}\left(\mathrm{NO}_{3}\right)_{2} \cdot 2 \mathrm{H}_{2} \mathrm{O}$ (Alpha Aesar, Bio Aqua Group, Targu Mures, Romania), iron nitrate nonahidrate- $\mathrm{Fe}\left(\mathrm{NO}_{3}\right)_{2} \cdot 9 \mathrm{H}_{2} \mathrm{O}$ (Alpha Aesar, Bio Aqua Group, Targu Mures, Romania), absolute ethanol $\mathrm{C}_{2} \mathrm{H}_{5} \mathrm{OH}-\mathrm{EtOH}$ (Merck, Redox Life Tech, Cluj-Napoca, Romania), and sodium hydroxide ( $\mathrm{NaOH}$ ) (Alpha Aesar, Bio Aqua Group, Targu Mures, Romania). All chemicals were of analytical grade and used without further purification. The aqueous solutions were prepared with Milli-Q water obtained from Direct-Q 3UV system (Millipore, Bedford, MA, USA).

\subsection{Synthesis of Fe-Doped $\mathrm{ZnO}$ Nanoparticles}

Fe doped $\mathrm{ZnO} N \mathrm{Ns}-\mathrm{ZnO}$ :Fex $(\mathrm{x}=0 \%, 0.3 \%, 0.5 \%, 0.7 \%, 1.0 \%)$ were synthesized by chemical precipitation. The $\mathrm{ZnO}$ :Fe nanoparticles were obtained according to literature data [67] with minor changes necessary for the purposes of this work.

In a typical procedure, stoichiometric amounts of $\mathrm{Zn}\left(\mathrm{NO}_{3}\right)_{2} \cdot 6 \mathrm{H}_{2} \mathrm{O}(98 \%)$ and $\mathrm{Fe}\left(\mathrm{NO}_{3}\right)_{2}$. $9 \mathrm{H}_{2} \mathrm{O}$ were dissolved in $100 \mathrm{~mL}$ of ultrapure water and mixed together to form a homogeneous solution. Subsequently, a solution of $2 \mathrm{M} \mathrm{NaOH}$ was added dropwise at a constant stirring rate until a white precipitate of zinc hydroxide was obtained. After $\mathrm{pH}=12$ was reached, the mixture was continuously stirred for $4 \mathrm{~h}$ at room temperature. The obtained $\mathrm{ZnO}$ :Fex was washed with ultrapure water and then dried at $65^{\circ} \mathrm{C}$ for $24 \mathrm{~h}$.

\subsection{Processing of PLA Film}

Homogenous PLA films with dimensions $150 \times 150 \times 0.1 \mathrm{~mm}$ were obtained by hot-pressed on a laboratory press under the following conditions: preheating for $5 \mathrm{~min}$ at 150 bar and pressing for $2 \mathrm{~min}$, at a pressure of $150 \mathrm{bar}$, both at $190{ }^{\circ} \mathrm{C}$, followed by cooling for $45 \mathrm{~min}$ and 150 bar.

\subsection{Coating of PLA Films with PHBV/ZnO:Fe Electrospun Nanosystems}

First, $8 \mathrm{wt} \%$ PHBV solution was prepared by dissolving PHBV pellets in a mixture of dichloromethane and ethanol at a vol. ratio of $6: 1$ between solvents by using a laboratory mixer at a temperature of $60{ }^{\circ} \mathrm{C}$ and a speed mixing of $400 \mathrm{rpm}$, for $2 \mathrm{~h}$. After obtaining a homogeneous solution, $1 \mathrm{wt} \%$ of Fe-doped $\mathrm{ZnO}$ antimicrobial agent containing: $0 \mathrm{wt} \%$, $0.3 \mathrm{wt} \%, 0.5 \mathrm{wt} \%, 0.7 \mathrm{wt} \%$, and $1 \mathrm{wt} \%$, respectively, of Fe was incorporated in the prepared PHBV solution. The resulted solutions coded PHBV:ZnO:Fe0, PHBV:ZnO:Fe0.3, PHBV:ZnO:Fe0.5, PHBV:ZnO:Fe0.7, and PHBV:ZnO:Fe1 were introduced into a syringe pump, having as a pin a pointless stainless steel needle, with an internal diameter of $0.168 \mathrm{~mm}$. Nanofibers based on PHBV and $1 \mathrm{wt} \% \mathrm{ZnO}: F e x$ NPs with different content of Fe were deposited onto PLA films by the electrospinning process using an uniaxial electrospinning equipment (TL Pro-BM, Tong Li Tech Co., Ltd., Bao An, Shenzhen, China), at a voltage in the range of $16.3-16.7 \mathrm{kV}$, a flow rate between 0.4 to $3.6 \mathrm{~mL} / \mathrm{h}$ and $14 \mathrm{~cm}$ being the distance between the needle to cylindrical disc collector. The electrospinning process was performed in an environment under temperature of $28.5 \pm 1.5^{\circ} \mathrm{C}$ and relative humidity of $28 \pm 1 \%$. Nanofibers of PHBV deposited onto PLA film and PLA films were used for comparative purposes.

\subsection{Investigation Methods}

\subsubsection{Particle Size Distribution}

The size measurements of Fe-doped $\mathrm{ZnO}$ nanoparticles were performed by a dynamic light scattering (DLS) technique (Zetasizer Nano ZSP, Malvern Instruments, Malvern, UK), 
and the scattered light was collected at $173^{\circ}$, with a red laser wavelength of $632.8 \mathrm{~nm}$ $(\mathrm{He} / \mathrm{Ne})$. In addition, $0.1 \mathrm{~g}$ of each doped $\mathrm{ZnO}$ were immersed in $5 \mathrm{~mL}$ of ultrapure water and sonicated for $5 \mathrm{~min}$. Then, 3 suspension drops were dispersed into $10 \mathrm{~mL}$ solution $1 \mathrm{mM} \mathrm{NaCl}$, homogenized again and analyzed by using a $12 \mathrm{~mm}$ cell (DTS 0012). Measurements of $Z$ average, size, and polydispersity index were performed in triplicate, and the results are expressed as mean values \pm standard deviation.

\subsubsection{Scanning Electron Microscopy (SEM)}

SEM analysis was done using Hitachi SU-8230 (Tokyo, Japan) with a cold field emission gun at $30 \mathrm{kV}$. Before the analysis, all samples were sputter coated with $10 \mathrm{~nm} \mathrm{Au}$ in Ar atmosphere. Energy dispersive X-ray analysis (EDX) was done using an Oxford Instruments detector (Oxford, UK) and AZtech software (Greeley, CO, USA).

\subsubsection{Structural Analysis by X-ray Diffraction}

The structural characterization and crystalinity degree for PLA/PHBV/ZnO:Fex samples were also investigated by a Bruker D8 Advance Diffractometer (Rheinstetten, Baden-Württemberg, Germany) in Bragg Brentano geometry equipped with Ge(111) in the incident beam, a fast LynxEye detector, and $\mathrm{Cu}-\mathrm{K} \alpha 1$ radiation $(\lambda=1.54060 \AA),(40 \mathrm{kV}$, $40 \mathrm{~mA}$ ) over the range of $2 \theta=3-70^{\circ}$, at ambient temperature. Before being embedded into PHBV, ZnO:Fex nanoparticles were structurally characterized. The crystallite dimensions were determined with MATCH software (Kreuzherrenstr, Germany).

\subsubsection{Fourier Transform Infrared Spectroscopy (FT-IR)}

The PHBV/ZnO:Fex nanosystems were analyzed in reflection mode, at room temperature, by means of an Atenuated Total Reflectance-FT-IT (INTERSPEC 200-X Spectrophotometer, Interspectrum, Tartumaa, Estonia) having a ZnSe crystal with an incidence angle of $45^{\circ}$. All spectra were acquired in a wavenumber range from 3500 to $750 \mathrm{~cm}^{-1}$, at $4 \mathrm{~cm}^{-1}$ resolution, as the average of 20 scans, using air as background. PLA film and PHBV nanofibers deposited onto PLA film were used for comparative purposes.

\subsubsection{X-ray Photoelectron Spectroscopy (XPS)}

X-ray photoelectron spectroscopy (XPS) analysis was performed with a SPECS custombuild (Berlin, Germany) using Al K $\alpha$ X-rays (1486.61 eV). Each sample showed several Ar ions etchings until the XPS spectra remained unchanged in shape and intensity. At this stage, the XPS spectra reflect the real composition of samples. In order to avoid artificial reduction of different oxidation stats of elements, the etching was performed by using Ar ions accelerated at a maximum $1000 \mathrm{~V}$ voltage with a filament current of $10 \mathrm{~mA}$. XPS spectrum analysis was performed with CasaXPS software. Spectrum calibration was done considering the $284.6 \mathrm{eV} \mathrm{C} 1$ s line associated with $\mathrm{C}-\mathrm{C}$ or $\mathrm{C}-\mathrm{H}$ bindings.

\subsubsection{Migration Tests}

Specific migration tests were performed in ethanol 10\% $(v / v)$ (food simulant A) and acetic acid 3\% (w/w) (food simulant type B) and by using sample ashes treated with 3\% nitric acid $\left(\mathrm{HNO}_{3}\right)$ solution. Two-faced migration was performed by immersing circular specimens of $3.14 \mathrm{~cm}^{2}$ total area of each sample in plastic vials containing $20 \mathrm{~mL}$ of food simulants to keep the relation $6 \mathrm{dm}^{2} \mathrm{~kg}^{-1}$ as it is indicated in the current legislation [28]. The samples were stored in a controlled atmosphere at $70{ }^{\circ} \mathrm{C}$ during $2 \mathrm{~h}$. Blank simulants were also prepared and analyzed in each case.

After the migration tests, films were removed and simulants were analyzed for $\mathrm{ZnO}$ and Fe released by Inductive Coupled Plasma Mass Spectrometry detection (ICP-MS Agilent 7500a, Palo Alto, CA, USA). In addition, the content of inorganic material was determined by testing the ash resulting from the calcination of the samples at a temperature of $550{ }^{\circ} \mathrm{C}$ for $1.30 \mathrm{~h}$. The ash was suspended in approximately $50 \mathrm{~mL}$ of $3 \% \mathrm{HNO}_{3}$ solution 
$(v / v)$. The samples were stored in the refrigerator until the analysis. All samples were tested in triplicate.

The detection was performed using the following conditions: 5 repetitions of each mass; full-spectrum mode, acquisition time was $0.3 \mathrm{~s}$ per mas; and peristaltic pump aspiration speed was set at 0.3 revolutions per second.

Calibration curves were prepared with standard solutions of $\mathrm{Zn}$ and Fe in each simulant as well as in 3\% nitric acid. The following concentration ranges were used in case of Fe calibration curves: $20-1000 \mathrm{ng} / \mathrm{mL}$ ( $3 \%$ acetic acid), $116-1000 \mathrm{ng} / \mathrm{mL}$ (10\% ethanol), and $10-1000 \mathrm{ng} / \mathrm{mL}$ ( $3 \%$ nitric acid). In the case of $\mathrm{Zn}$, the calibration curves covered the concentration ranges: $10-1000 \mathrm{ng} / \mathrm{mL}$ ( $3 \%$ acetic acid), $27-1000 \mathrm{ng} / \mathrm{mL}$ ( $10 \%$ ethanol), and 3-1000 $\mathrm{ng} / \mathrm{mL}$ (3\% nitric acid). The limits of detection (LOD) and quantification (LOQ) were calculated as the average signal of blank plus three (LOD) and ten (LOQ) times its standard deviation.

\subsubsection{Bacterial Adherence}

Pseudomonas aeruginosa (ATCC-27853) was used for this analysis. The tested microorganism was obtained from Food Biotechnology Laboratory, Life Sciences Institute, University of Agricultural Sciences and Veterinary Medicine Cluj Napoca, Romania. The bacteria were cultured on Muller-Hinton Agar and cultures were stored at $4{ }^{\circ} \mathrm{C}$ and sub-cultured once a month. The bacterial adherence was tested to simulate the affinity of microorganisms to the implant surface, directly after implantation. A protocol adapted from Tanner et al. [68] was applied for the P. aeruginosa on both uncoated and coated specimens. The bacteria were precultured from a frozen glycerol preparation and inoculated in $45 \mathrm{~mL}$ Tryptic Soy Broth for $16 \mathrm{~h}$ at $37^{\circ} \mathrm{C}$. After harvesting the bacteria by centrifugation $(4000 \mathrm{rpm}$, $+4{ }^{\circ} \mathrm{C}, 10 \mathrm{~min}$ ), they were washed once with a physiological sterile saline solution. Then, cells were re-suspended in physiological saline solution at a concentration of $\sim 0.035 \%$, and the absorbance was measured at $550 \mathrm{~nm}$, which corresponded to $\sim 1 \times 10^{7}$ colony-forming units (CFU). The suspension was gently sonicated and vortexed to homogenize the solution. Then, the specimens were placed in $15 \mathrm{~mL}$ test tubes with $5 \mathrm{~mL}$ of the bacterial suspension. After $30 \mathrm{~min}$ at room temperature, the specimens were washed three times in abundant physiological saline solution and gently dried without touching the surface. Thereafter, the bacterial samples from the specimen surfaces were collected for analysis of viability with micro brushes into $2 \mathrm{~mL}$ microtubes containing $900 \mu \mathrm{L}$ of Tryptic Soy Broth with 10\% glycerol. Then, the bacteria were homogenized, serially diluted in physiological saline solution (10 $\mu \mathrm{L}$ of 1:10, 1:100, and 1:1000), and cultured on Muller-Hinton agar plates. CFU measurements were done after $24 \mathrm{~h}$ of culturing at $37^{\circ} \mathrm{C}$.

\subsubsection{Evaluation of the Reactive Oxygen Species (ROS) Generation}

By using the Electron Spin Resonance (ESR) also known as Electron Paramagnetic Resonance (EPR) coupled with the spin-trapping probe technique, the ROS production of PLA/PHBV/ZnO:Fex in DMSO (dimethyl sulfoxide) suspensions was monitored. In addition, 5,5-dimethyl-1-pyrroline N-oxide (DMPO, Sigma-Aldrich, Merck, KGaA, Darmstadt, Germany) was used as a spin trapping agent. The samples were investigated by dispersing $10 \mathrm{mg}$ of PLA/PHBV/ZnO:Fex in $1 \mathrm{~mL}$ of DMSO. These suspensions were homogenized in an ultra-sound bath (30 s) before use. The DMPO concentration was $0.2 \mathrm{M}$. The PLA/PHBV/ZnO:Fe 0.3\% sample was transferred into the quartz cell of spectrophotometer optimized for liquid measurements, and the experimental spectra were recorded. The measurements were recorded with a Bruker E-500 ELEXSYS X-band $(9.52 \mathrm{GHz})$ spectrometer (Rheinstetten, Baden-Württemberg, Germany) in the same experimental conditions.

\subsubsection{Statistical Analysis}

All data were expressed as the mean \pm standard deviation of the mean. Statistical analysis was performed by using GraphPad Prism 8 software. 


\section{Results and Discussion}

\subsection{Dimension Size Measurement}

The analysis of the dimensional distribution and size of the prepared $\mathrm{ZnO}$ :Fex nanoparticles was determined by the spectroscopic correlation of the photons by the laser diffusion technique (DLS) as can be seen in Figure 1 and Table 1.

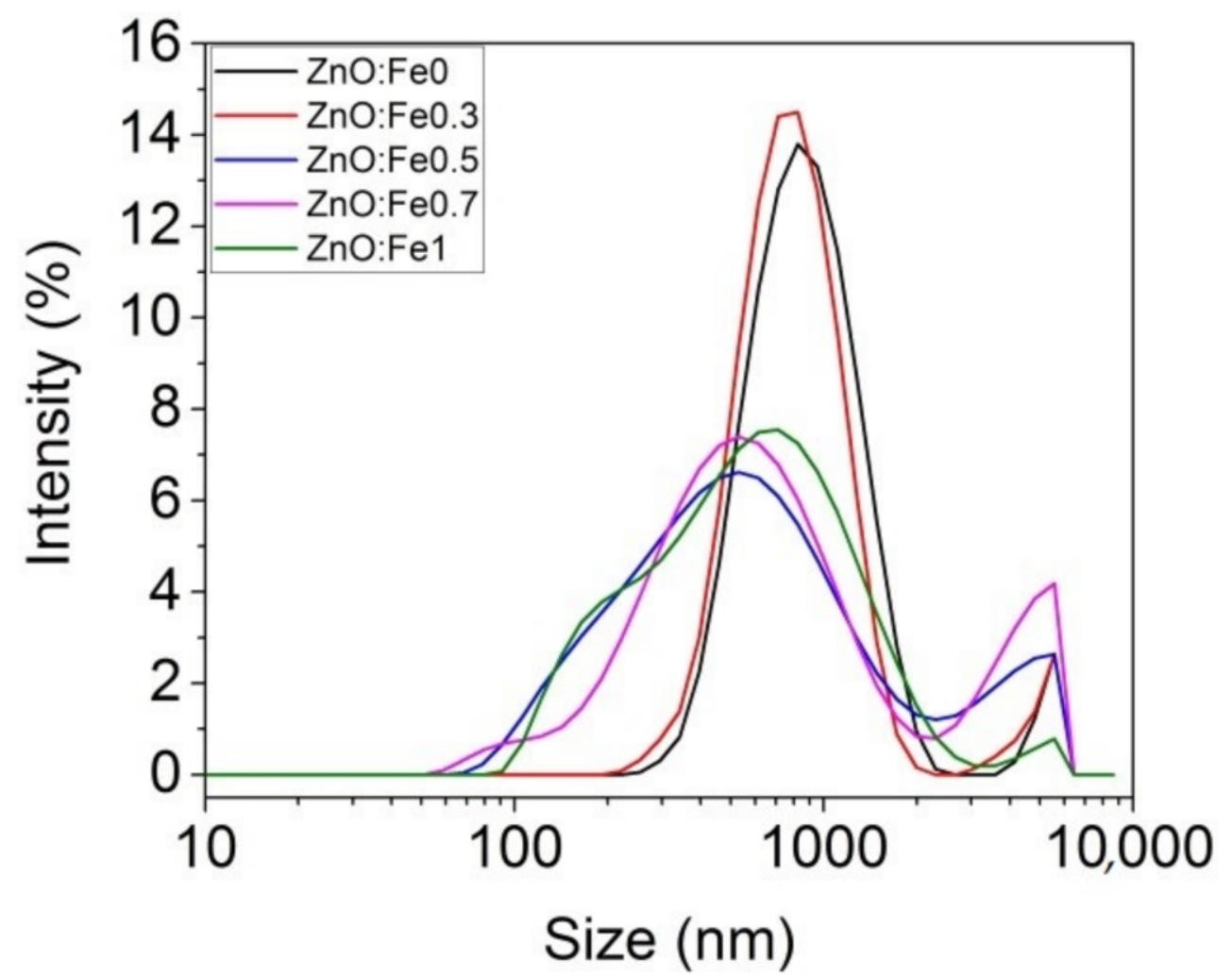

Figure 1. Size distribution of $\mathrm{ZnO}$ :Fex nanoparticles.

Table 1. Zetasizer parameters for Fe-doped $\mathrm{ZnO}$ nanoparticles determined from DLS analysis.

\begin{tabular}{|c|c|c|c|c|c|c|}
\hline \multirow{2}{*}{ Fe-Doped ZnO } & \multirow{2}{*}{ Average Z (nm) } & \multicolumn{2}{|c|}{ Size } & \multicolumn{2}{|c|}{ Intensity } & \multirow{2}{*}{ Pdi } \\
\hline & & Peak 1 (nm) & Peak $2(\mathrm{~nm})$ & Peak $1(\%)$ & Peak 2 (\%) & \\
\hline $\mathrm{ZnO}: \mathrm{Fe} 0$ & 780.1 & $900.2 \pm 1.5$ & $5280 \pm 126$ & 95.8 & 4.2 & 0.347 \\
\hline $\mathrm{ZnO}: \mathrm{Fe} 0.3$ & 818.6 & $805.4 \pm 48.8$ & $5201 \pm 387$ & 94.7 & 5.3 & 0.338 \\
\hline $\mathrm{ZnO}: \mathrm{Fe} 0.5$ & 460.0 & $608.8 \pm 76.8$ & $4143 \pm 653$ & 86.8 & 13.3 & 0.456 \\
\hline $\mathrm{ZnO}: \mathrm{Fe} 0.7$ & 443.0 & $670.0 \pm 0.3$ & $5021 \pm 0$ & 98.0 & 1.7 & 0.388 \\
\hline $\mathrm{ZnO}: \mathrm{Fe} 1$ & 444.5 & $685.3 \pm 21.6$ & $4882 \pm 197$ & 98.1 & 1.9 & 0.384 \\
\hline
\end{tabular}

Table 1 shows that the average $\mathrm{Z}$ decreased with the increase of Fe in $\mathrm{ZnO}$ NPs. $\mathrm{ZnO}: F e x$ nanoparticles are polydispersed (polydispersity index (Pdi) $<0.4$ ) and showed two peaks with different intensities in the band ranging from $608 \mathrm{~nm}$ to $900 \mathrm{~nm}(>86 \%$ distribution) and from $4143 \mathrm{~nm}$ to $5280 \mathrm{~nm}$ (<13\% distribution), respectively (Table 1).

\subsection{Scanning Electron Microscopy/Energy Dispersive X-ray (SEM/EDX) Analysis}

Before the incorporation in the prepared PHBV solution, the $\mathrm{ZnO}$ :Fex nanoparticles were investigated by TEM and SEM. As an example, TEM and SEM images of pure ZnO and $\mathrm{ZnO}: \mathrm{Fe}$ 0.7\% were recorded and shown in Figures 2 and 3, respectively. 


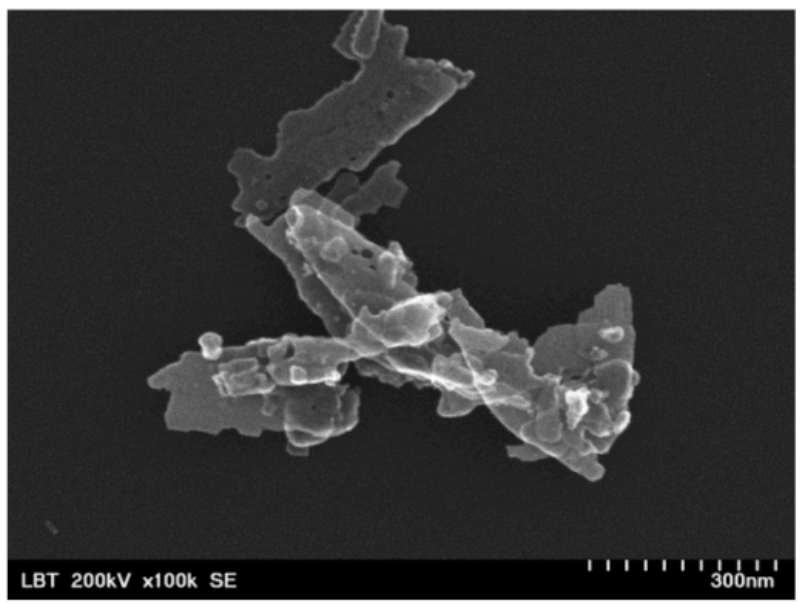

(a)

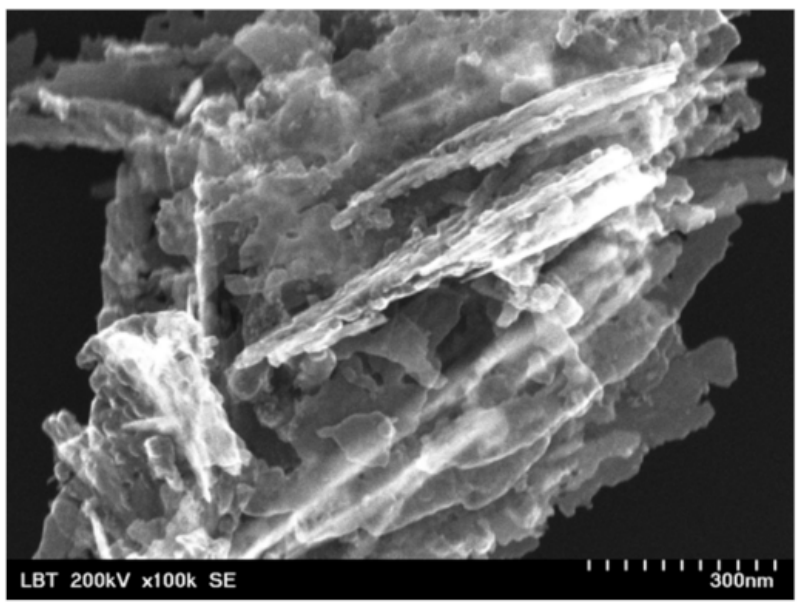

(b)

Figure 2. SEM images for $\mathrm{ZnO}$ :Fex nanostructures: (a) $\mathrm{ZnO}: \mathrm{Fe} 0$ and (b) $\mathrm{ZnO}: \mathrm{Fe} 0.7$.

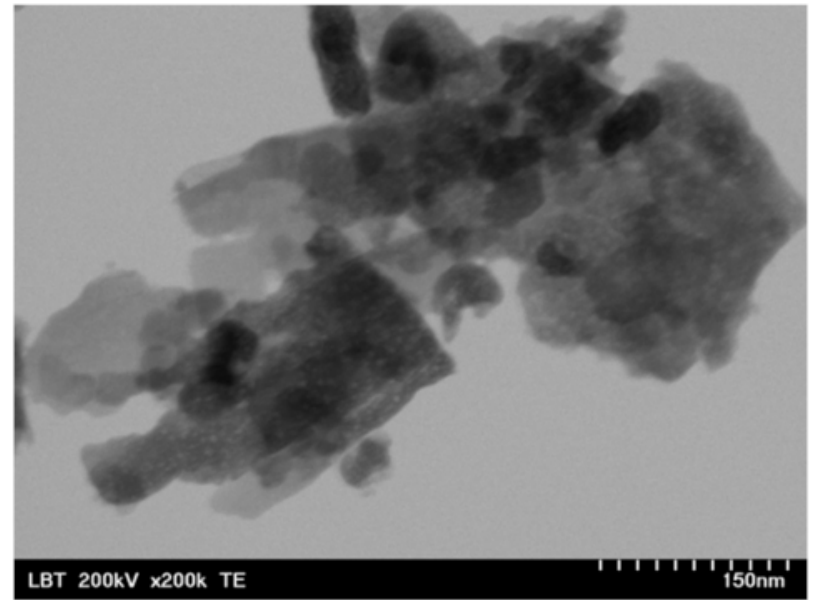

(a)

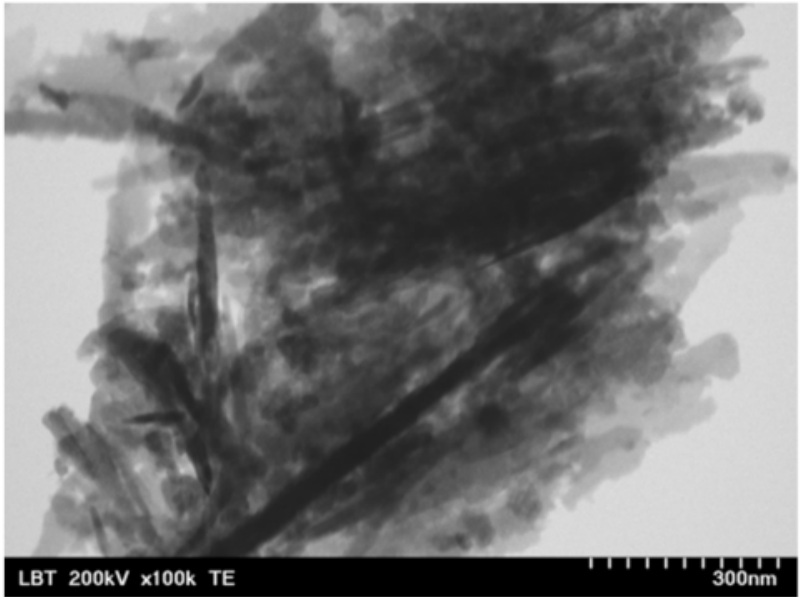

(b)

Figure 3. TEM images for $\mathrm{ZnO}: F e x$ nanostructures: (a) $\mathrm{ZnO}: \mathrm{Fe} 0$ and (b) $\mathrm{ZnO}: \mathrm{Fe} 0.7$.

The images show that $\mathrm{ZnO}$ and $\mathrm{ZnO}: \mathrm{Fe} 0.7 \%$ nanoparticles have a aggregated "sheets" like morphology with different lengths and sizes [69].

SEM micrographs revealed a uniformly distributed PHBV containing ZnO:Fex nanostructures with "beads" morphology (Figure 4). The presence of random PLA/PHBV/ZnO: Fex clusters was also noticed, most likely from the electrospinning solution.

Energy Dispersive X-ray Analysis (EDX) allowed the elemental composition of PLA/ PHBV/ZnO:Fex nanostructures. The elemental compositions are presented in Table 2. EDX analysis revealed the PLA/PHBV/ZnO:Fex elemental composition: C ( $\sim 59 \mathrm{wt} \%)$, Zn (increasing concentrations $0.1-1 \mathrm{wt} \%), \mathrm{O}(\sim 40 \mathrm{wt} \%)$ as main constituents and $\mathrm{Cu}$ from the sample support material. Fe concentration was under the detection limit of the analysis. 


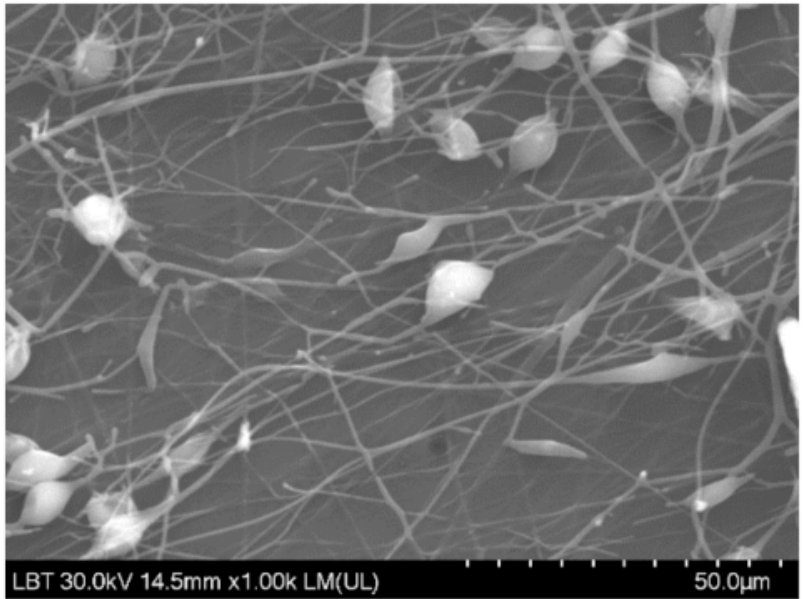

(a)

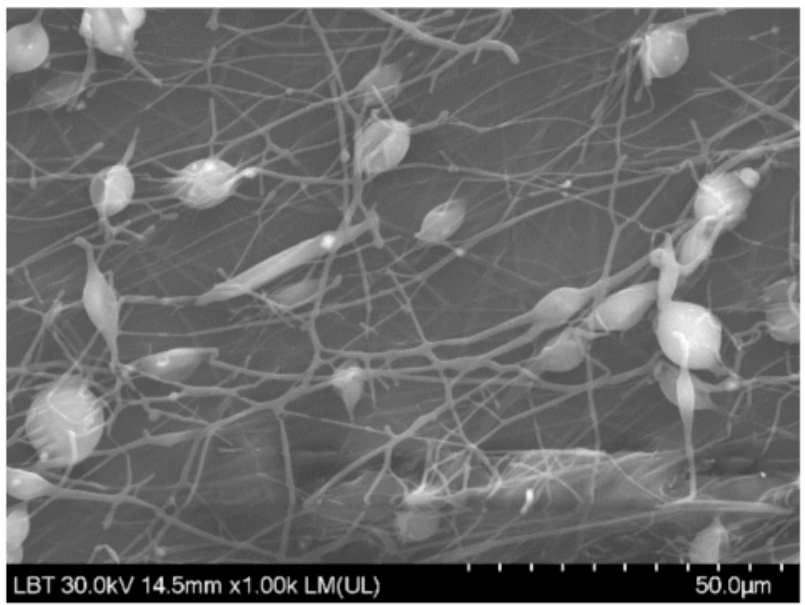

(c)

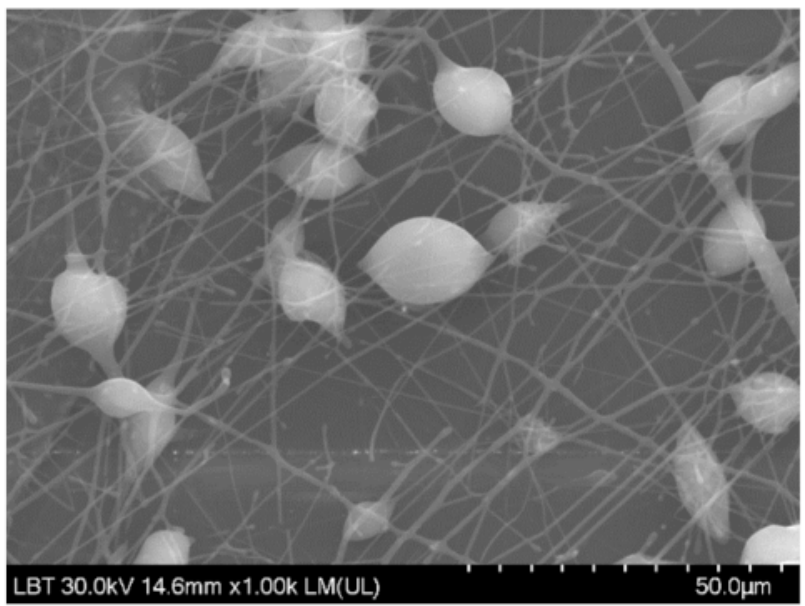

(e)

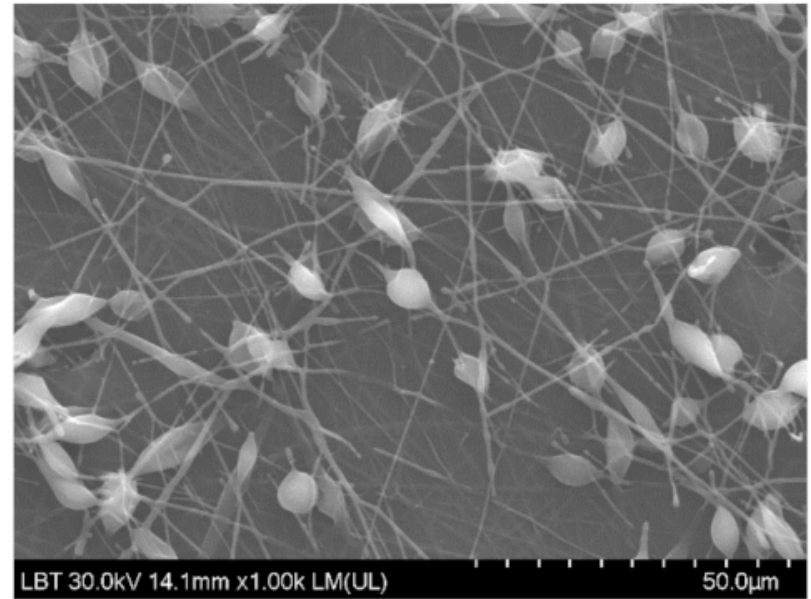

(b)

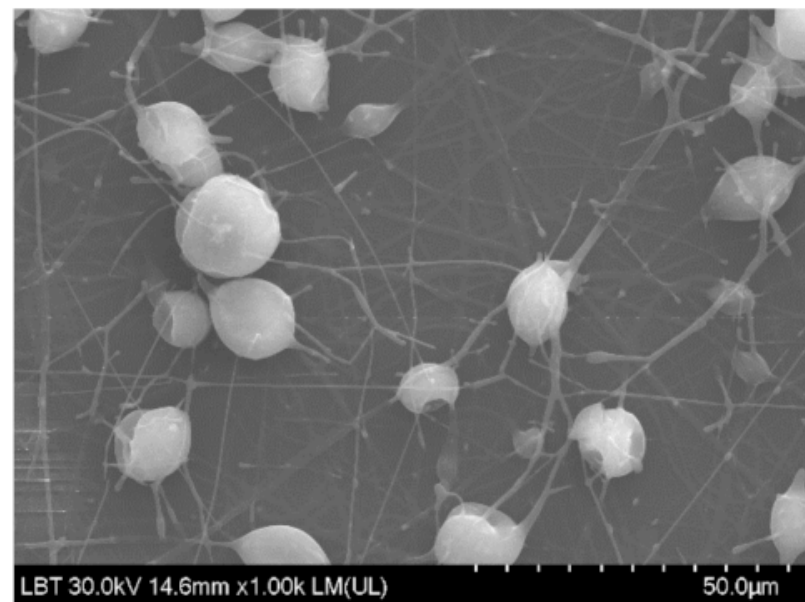

(d)

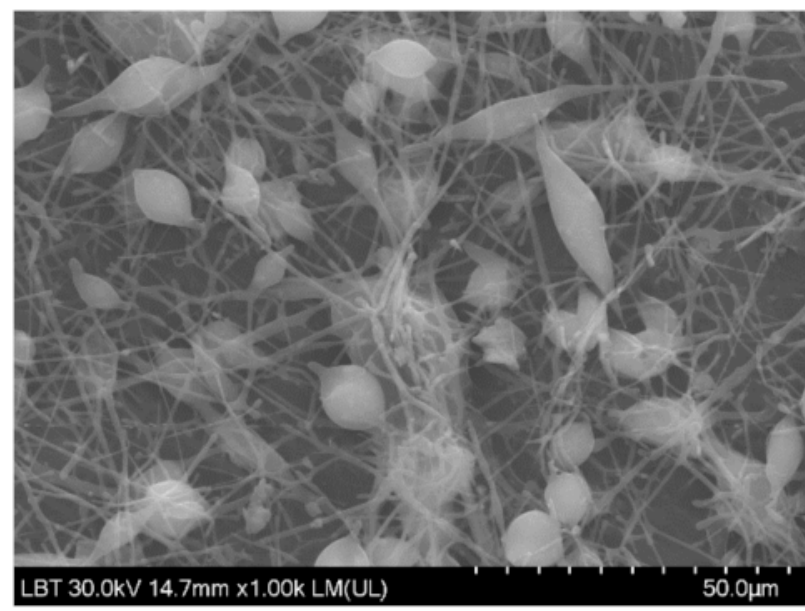

(f)

Figure 4. SEM images for PLA/PHBV/ZnO:Fex nanostructures: (a) PLA/PHBV, (b) PLA/PHBV/ ZnO:Fe0, (c) PLA/PHBV/ZnO:Fe0.3, (d) PLA/PHBV/ZnO:Fe0.5, (e) PLA/PHBV/ZnO:Fe0.7, and (f) PLA/PHBV/ZnO:Fe1. 
Table 2. Elemental chemical composition of PLA/PHBV/ZnO:Fex nanostructures determined from EDX analysis.

\begin{tabular}{ccccc}
\hline Nanostructures & $\mathbf{C}\left(\mathbf{w t} \% \pm \mathbf{2} \boldsymbol{\sigma}^{*}\right)$ & $\mathbf{O}(\mathbf{w t} \mathbf{\%} \pm \mathbf{2} \boldsymbol{\sigma})$ & $\mathbf{C u}(\mathbf{w t} \mathbf{0} \pm \boldsymbol{\sigma})$ & $\mathbf{Z n}(\mathbf{w t} \mathbf{\%} \pm \boldsymbol{\sigma})$ \\
\hline PLA/PHBV & $59.1 \pm 0.3$ & $40.8 \pm 0.3$ & $0.1 \pm 0.01$ & 0 \\
PLA/PHBV/ZnO:Fe0 & $59.0 \pm 0.3$ & $40.0 \pm 0.3$ & $0.1 \pm 0.01$ & $1.0 \pm 0.01$ \\
PLA/PHBV/ZnO:Fe0.3 & $56.9 \pm 0.3$ & $42.5 \pm 0.3$ & $0.2 \pm 0.01$ & $0.7 \pm 0.01$ \\
PLA/PHBV/ZnO:Fe0.5 & $58.7 \pm 0.3$ & $40.5 \pm 0.3$ & $0.2 \pm 0.01$ & $0.5 \pm 0.01$ \\
PLA/PHBV/ZnO:Fe0.7 & $59.0 \pm 0.3$ & $40.4 \pm 0.3$ & $0.3 \pm 0.01$ & $0.2 \pm 0.01$ \\
PLA/PHBV/ZnO:Fe1 & $60.0 \pm 0.3$ & $39.5 \pm 0.3$ & $0.3 \pm 0.01$ & $0.1 \pm 0.01$ \\
\hline
\end{tabular}

* $( \pm 2 \sigma) \mathrm{wt} \%$ calculated automatically within the software, should not be taken as absolute measurement of precision.

The distribution of $\mathrm{ZnO}: \mathrm{Fe}$ nanoparticles into the polymer matrix was analyzed by the EDS mapping. As an example, the EDS mapping of PLA/PHBV/ZnO:Fe1\% is shown in Figure 5. The mapping indicates the presence of $\mathrm{ZnO}: \mathrm{Fe}$ nanoparticles within both spheroidal structures and the fibers which connect them. The spheroids are formed around bundles of $\mathrm{ZnO}$ :Fe nanoparticles resulting from a non-uniform dispersion in the PHBV solution. Here, $\mathrm{ZnO}$ nanoparticles tend to agglomerate as long as their dispersion in the polymer matrix is not stabilized.

EDS Layered Image 1
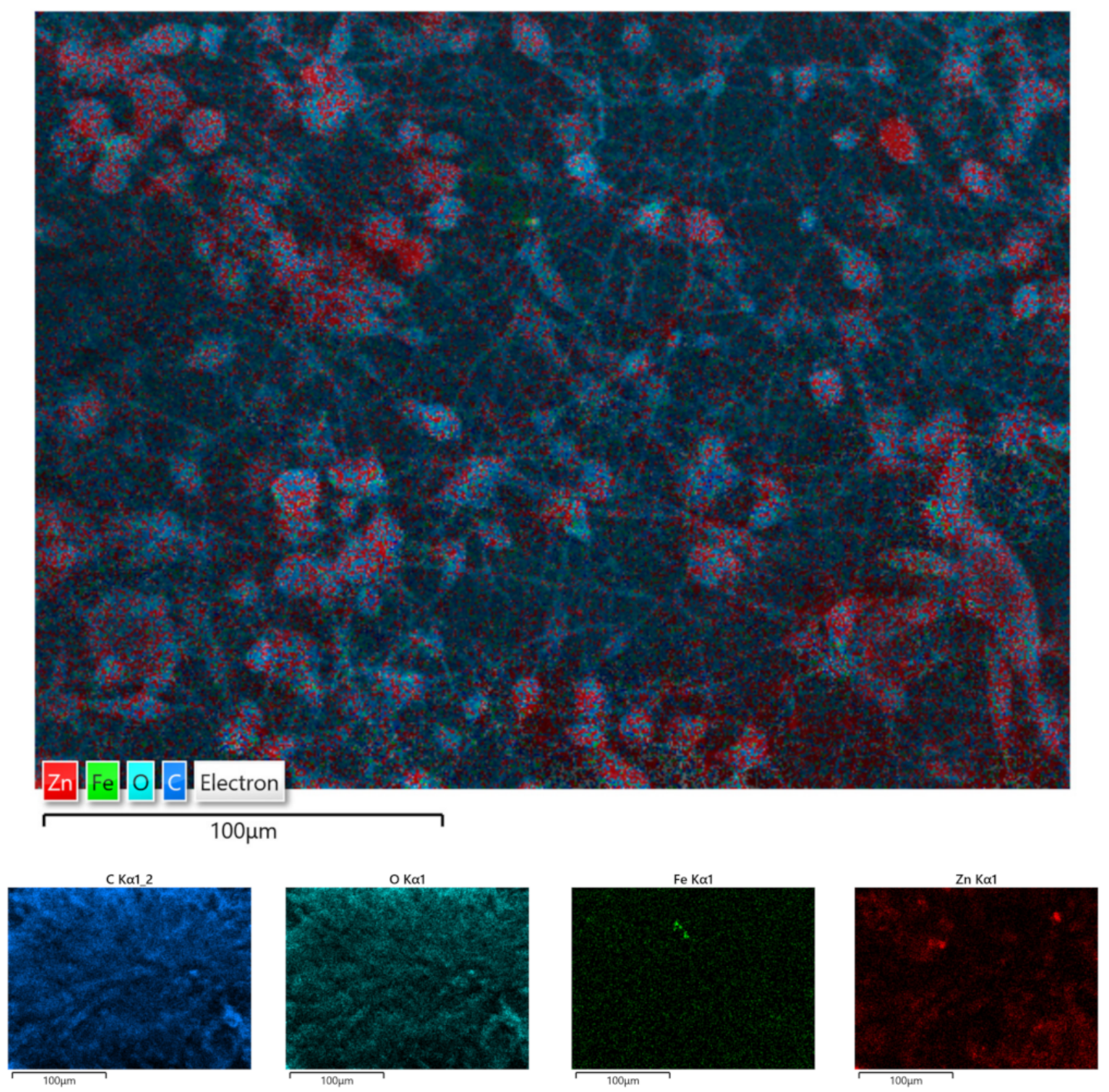

Figure 5. EDS mapping of PLA/PHBV/ZnO:Fe1\%. 


\subsection{X-ray Diffraction}

Structural characterization and crystallinity degree of PLA/PHBV/ZnO:Fex samples were investigated by $\mathrm{X}$-ray Diffraction (XRD).

Figure 6 shows the diffraction patterns of ZnO, PLA, PLA/PHBV, and PLA/PHBV/ $\mathrm{ZnO}:$ Fex composite samples.

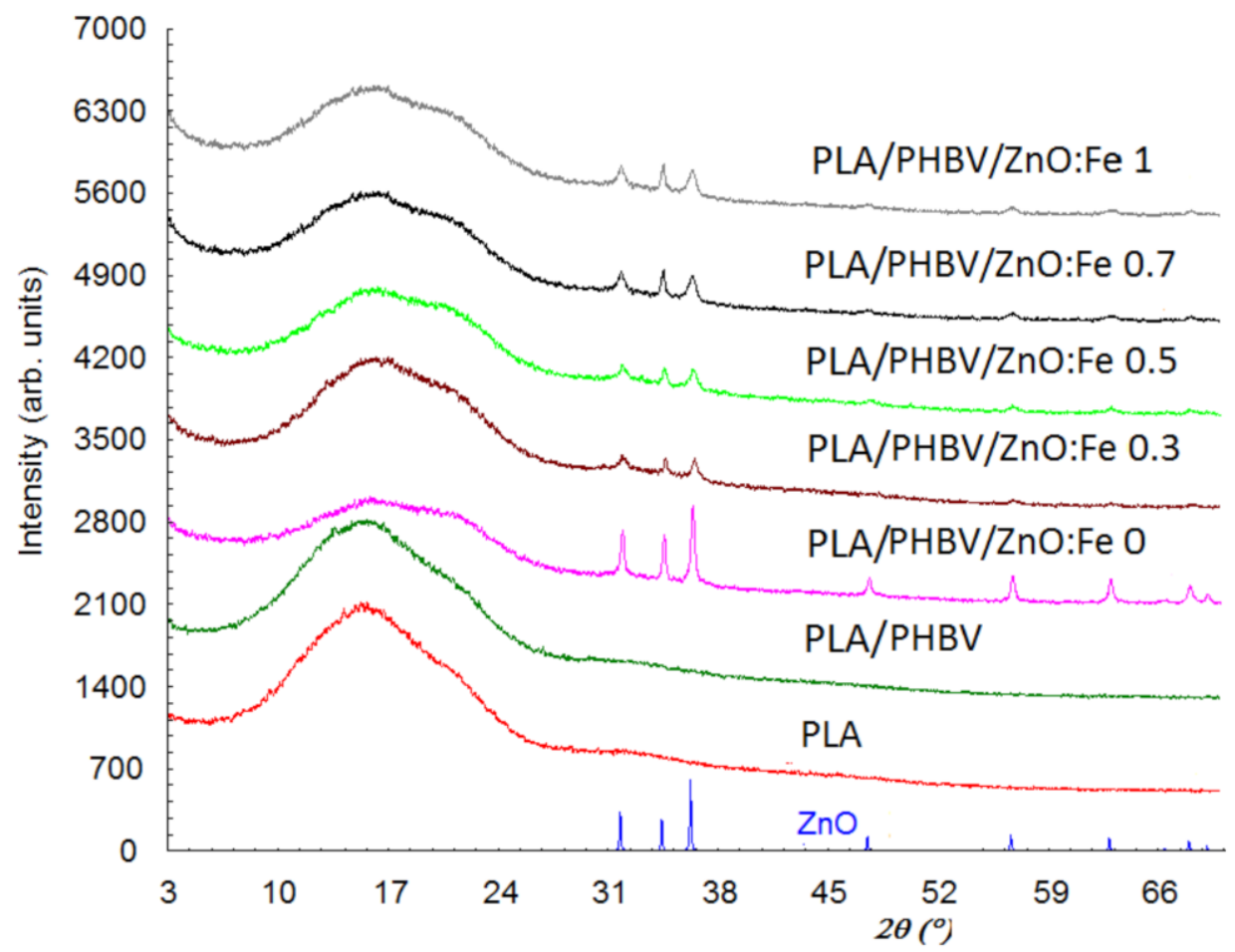

Figure 6. X-ray diffraction patterns of PLA/PHBV/ZnO:Fex samples compared with ZnO NPs, PLA film, and PHBV nanofibers.

X-ray diffraction patterns for the PLA and PHBV samples show that they have only one amorphous phase, while the other samples show both the amorphous and crystalline phase due to the $\mathrm{ZnO}$ incorporation. The diffractogram for the amorphous phase shows two diffraction halos-one of them with a maximum at about $2 \theta=16^{\circ}$, and the other halo with lower intensity and shielded by the diffraction lines of $\mathrm{ZnO}$ is found at about $32^{\circ}$. In addition, the first diffraction halo at $2 \theta=16^{\circ}$ seems to be split. The interplanar distance (d) corresponding to $2 \theta=16^{\circ}$ is $5.6 \AA$ and, for $2 \theta=32^{\circ}$, it is $2.8 \AA$. This suggests that the PLA are stratified, $5.6 \AA$ being the distance between layers and the diffraction angles corresponding for the two halos are the order 1 and order 2 of diffraction from the Bragg relationship. The diffraction peaks at 20: 31.75, 34.40, 36.24, 47.51, 56.60, 62.80, and $67.90^{\circ}$ in PLA/PHBV/ZnO:Fex samples indicate the presence of the $\mathrm{ZnO}$ crystalline phase. Although the amount of $\mathrm{ZnO}$ in samples has a maximum of $1 \%$, the diffraction maxima are prominent since the $\mathrm{ZnO}$ phase is evenly distributed on the sample surface and the diffraction information is collected from the surface (usually $0.1 \mathrm{~mm}$ ). The degree of crystallinity, $X_{c}$, was evaluated as the ratio of the diffraction peaks' area and the total diffraction area, which includes diffraction peaks and amorphous halo [70]. To assess the degree of crystallinity, the Reflex computer program part of the Material Studio software suite was used [71]. The values obtained for $X_{\mathrm{C}}$ are summarized in Table 3. The degree of crystallinity is $100 \%$ for $\mathrm{ZnO}$ nanoparticles and, for PLA and PHBV, is close to $0 \%$. 
Table 3. The degree of crystallinity (Xc) for PLA/PHBV/ZnO:Fex samples.

\begin{tabular}{cc}
\hline Sample & Xc (\%) \\
\hline PLA/PHBV/ZnO:Fe0 & 8.34 \\
PLA/PHBV/ZnO:Fe0.3 & 8.43 \\
PLA/PHBV/ZnO:Fe0.5 & 10.16 \\
PLA/PHBV/ZnO:Fe0.7 & 10.44 \\
PLA/PHBV/ZnO:Fe1 & 8.42 \\
\hline
\end{tabular}

In the case of PHBV / ZnO electrospun nanosystems used to coat PLA films, the doping with Fe decreases the size of these crystallites ranging from $13 \mathrm{~nm}$ for $\mathrm{ZnO}$ to $11.5 \mathrm{~nm}$ for $\mathrm{ZnO}: \mathrm{Fe} 0.3 \%$.

\subsection{ATR-FT-IR Analysis}

FT-IR analysis was performed on PLA/PHBV/ZnO:Fex electrospun samples compared with PLA film to identify the effect of $\mathrm{ZnO}$ :Fex on the chemical structure of nanosystems.

The PLA film spectrum showed two small absorption peaks located at $2992 \mathrm{~cm}^{-1}$ and $2947 \mathrm{~cm}^{-1}$ (symmetric and asymmetric C-H stretching vibrations), a strong and sharp absorption peak at $1751 \mathrm{~cm}^{-1}$ ( $\mathrm{C}=\mathrm{O}$ stretching of the carbonyl group), $1452 \mathrm{~cm}^{-1}$ and $1368 \mathrm{~cm}^{-1}$ (C-C stretching vibrations), $1084 \mathrm{~cm}^{-1}$ (rocking vibrations of $\mathrm{CH}_{2}$ bond), $867 \mathrm{~cm}^{-1}$ and $751 \mathrm{~cm}^{-1}$ (amorphous and crystalline phases) as can be seen in Figure 7 [42,72]. The deposition of PHBV onto PLA film did not reveal an absorption peak at around $1720 \mathrm{~cm}^{-1}$ assigned to the vibration of crystalline stretching of $\mathrm{C}=\mathrm{O}$ carbonyl group in $\mathrm{PHBV}[73,74]$ because PLA and PHBV are incompatible polyesters. It is observed from Figure 7 that the incorporation of $\mathrm{ZnO}$ :Fe nanoparticles into the PHBV matrix revealed a prominent peak located at around $2790 \mathrm{~cm}^{-1}$, implying that there were hydrogen bond interactions between the vibrations of the $\mathrm{CH}_{2}$ group of PHBV and the hydroxyl group of the nanoparticles [44].

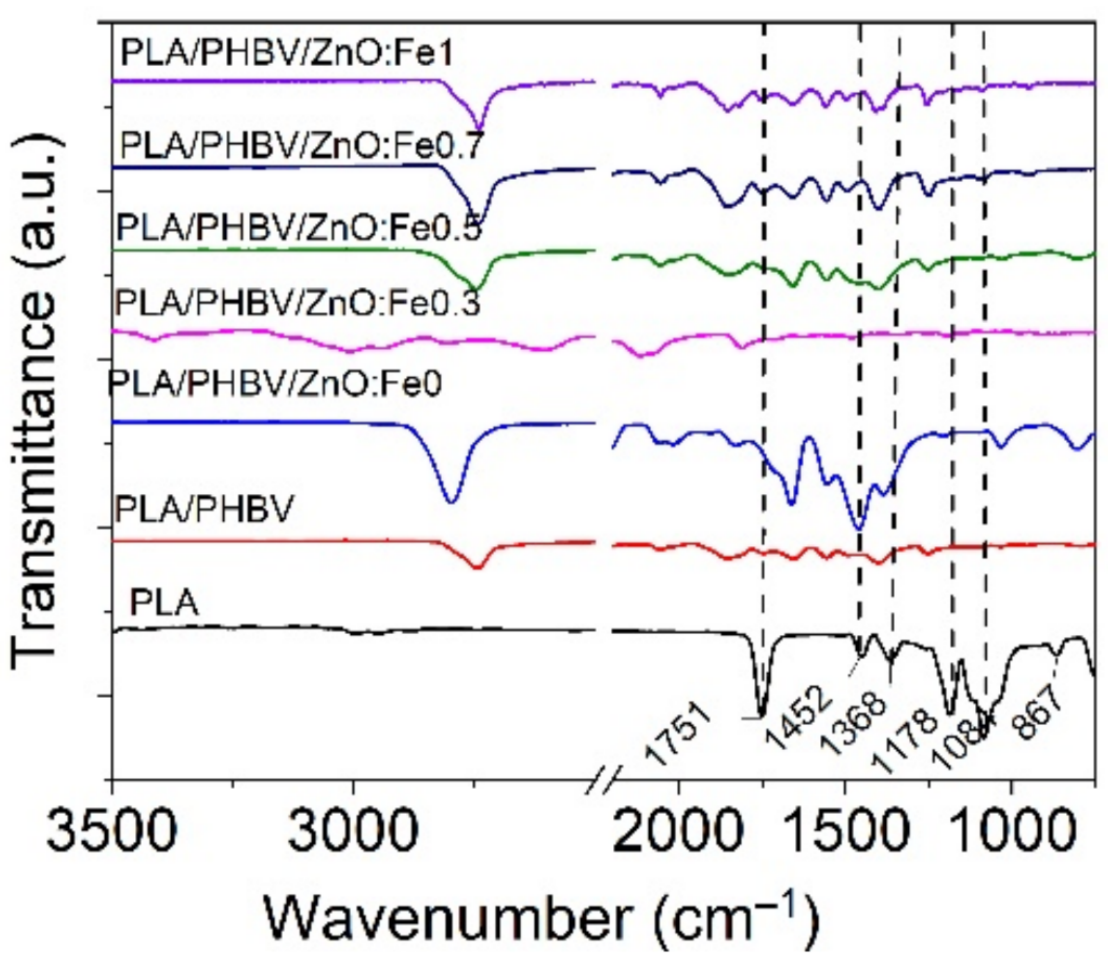

Figure 7. Normalized FT-IR spectra for PLA/PHBV/ZnO:Fex electrospun nanosystems compared with those for PLA film and PHBV nanofibers in the range of $3500-750 \mathrm{~cm}^{-1}$. 


\subsection{Qualitative Analysis by XPS}

The elemental composition of the nanocomposites was investigated by XPS. It is known that PLA degrades under X-ray radiation [75] and therefore the C1s spectrum was first recorded, followed by $\mathrm{Zn} 2 \mathrm{p}$ and O1s spectra. For example, Figure $8 \mathrm{a}, \mathrm{b}$ showed the $\mathrm{C} 1 \mathrm{~s}$ and $\mathrm{Zn} 2 \mathrm{p}$ core-level spectra, corresponding to the PLA/PHBV/ZnO:Fe0.3 sample. The deconvolution of the $\mathrm{C}$ 1s core level (Figure 5) was done by taking into account the specific lines for PLA and PHBV: $\mathrm{C}-\mathrm{C} / \mathrm{C}-\mathrm{H}, \mathrm{C}-\mathrm{O}$ and $\mathrm{C}=\mathrm{O}$. PLA is expected to show equal proportions of the components, while $\mathrm{PHBV}$ is expected to show a larger $\mathrm{C}-\mathrm{C} / \mathrm{C}-\mathrm{H}$ component. The $\mathrm{C}-\mathrm{C} / \mathrm{C}-\mathrm{H}$ component is bigger than expected due to the adventitious carbon contamination of the sample.
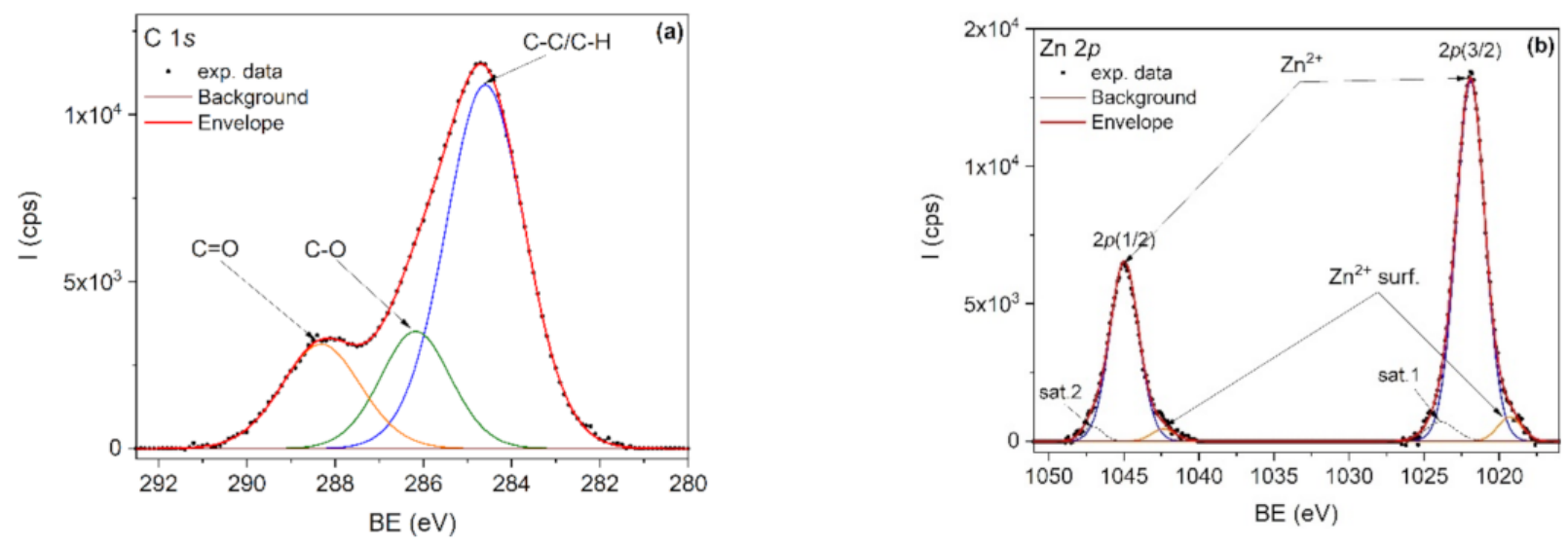

Figure 8. XPS spectra of PLA/PHBV/ZnO:Fe0.3 sample: (a) C 1s and (b) Zn 2p.

In the deconvolution of the $\mathrm{Zn} 2 \mathrm{p}$ doublet spectrum (Figure $8 b$ ), the $2 p(3 / 2)$ and $2 p(1 / 2)$ peaks positioned at 1021.9 and $1044.9 \mathrm{eV}$ are attributed to $\mathrm{Zn}^{2+}$ from the $\mathrm{ZnO}$ lattice. The doublet positioned at lower binding energies, namely $1019.3 \mathrm{eV}$ for $2 \mathrm{p}(3 / 2)$ and $1042.3 \mathrm{eV}$ for $2 \mathrm{p}(1 / 2)$, is attributed to $\mathrm{Zn}^{2+}$ surface states. Two shakeup satellites positioned at $1023.9 \mathrm{eV}$ and $1047.1 \mathrm{eV}$ were also used in spectra deconvolution.

\subsection{Migration Tests}

An ICP-MS was employed to quantify the $\mathrm{Zn}$ and Fe ions in PHBV / ZnO:Fex electrospun nanosystems. The LOD of the specific migration in 3\% acetic acid simulant, $10 \%$ ethanol simulant, and $3 \%$ nitric acid were: $6 \mathrm{ng} / \mathrm{mL}, 35 \mathrm{ng} / \mathrm{mL}$, and $3 \mathrm{ng} / \mathrm{mL}$, respectively, for Fe and $3 \mathrm{ng} / \mathrm{mL}, 8 \mathrm{ng} / \mathrm{mL}$ and $1 \mathrm{ng} / \mathrm{mL}$, respectively, for $\mathrm{Zn}$ - while the LOQ of the specific migration in 3\% acetic acid simulant, $10 \%$ ethanol simulant, and $3 \%$ nitric acid were: $20 \mathrm{ng} / \mathrm{mL}, 116 \mathrm{ng} / \mathrm{mL}$, and $10 \mathrm{ng} / \mathrm{mL}$, respectively, for Fe, and $10 \mathrm{ng} / \mathrm{mL}, 27 \mathrm{ng} / \mathrm{mL}$, and $3 \mathrm{ng} / \mathrm{mL}$, respectively, for $\mathrm{Zn}$.

According to Annex II of EU Commission Regulation 10/2011, the food packaging materials must not release substances in quantities exceeding the specific migration limits for $\mathrm{Fe}=48 \mathrm{mg} / \mathrm{kg}$ food or food simulant and $\mathrm{Zn}=5 \mathrm{mg} / \mathrm{kg}$ food or food simulant.

Table 4 shows that the results of specific migrations for $\mathrm{Zn}$ and Fe from PLA-based compositions coated with $\mathrm{PHBV}$ and Fe-doped $\mathrm{ZnO}$ nanostructures performed using food simulants $\mathrm{A}$ and $\mathrm{B}$ and also after the treatment of ash with $3 \%(v / v) \mathrm{HNO}_{3}$ do not exceed the limits specified by the current legislation. Moreover, some values are below the detection limit of the analytical method. In all the cases, the results are below the overall migration limit of $60 \mathrm{mg} / \mathrm{kg}$ of the food simulant as well as those specified for $\mathrm{Zn}$ and $\mathrm{Fe}$ in Annex II of the Regulation (EU) No. 10/2011. Among the three migration tests performed, it can be found that the Fe migration test in $\mathrm{HNO}_{3}$ solution is the most severe, while the $3 \%$ acetic acid solution is the most severe for $\mathrm{Zn}$ migration. Similar results were reported by Vasile et al. [63] in the case of testing the specific migration of $\mathrm{Zn}$ and $\mathrm{Cu}$ ions from plasticized PLA samples with embedded $\mathrm{Cu}$-doped $\mathrm{ZnO}$ powder functionalized with Ag 
nanoparticles' composites. The authors found that the migration of $\mathrm{Zn}$ was more sensitive that than of $\mathrm{Cu}$ both in acetic acid and ethanol food simulants [63]. This behavior can be explained by the strong ionization tendency of $\mathrm{Zn} \mathrm{[76].}$

Table 4. Specific migration of $\mathrm{Zn}$ and $\mathrm{Fe}$ in 3\% (wt/v) acetic acid, 10\% (v/v) ethanol, and, after the treatment of ash with $3 \%$ $(v / v) \mathrm{HNO}_{3}, 2 \mathrm{~h}$ at $70{ }^{\circ} \mathrm{C}$.

\begin{tabular}{|c|c|c|c|c|c|c|c|c|}
\hline \multirow{2}{*}{ Sample } & \multicolumn{2}{|c|}{ 3\% (wt/v) Acetic Acid } & \multicolumn{2}{|c|}{$10 \%(v / v)$ Ethanol } & \multicolumn{2}{|c|}{ Ash Treated with $3 \%(v / v) \mathrm{HNO}_{3}$} & \multicolumn{2}{|c|}{ Theoretical Content } \\
\hline & $\mathrm{Zn}, \mathrm{mg} / \mathrm{kg}$ & $\mathrm{Fe}, \mathrm{mg} / \mathrm{kg}$ & $\mathrm{Zn}, \mathrm{mg} / \mathrm{kg}$ & $\mathrm{Fe}, \mathrm{mg} / \mathrm{kg}$ & $\mathrm{Zn}, \mathrm{mg} / \mathrm{kg}$ & $\mathrm{Fe}, \mathrm{mg} / \mathrm{kg}$ & $\mathrm{Zn}, \mathrm{mg} / \mathrm{kg}$ & $\mathrm{Fe}, \mathrm{mg} / \mathrm{kg}$ \\
\hline PLA/PHBV/ZnO:Fe0 & 2.917 & $<\mathrm{LOD}$ & 0.233 & $<\mathrm{LOD}$ & $<\mathrm{LOD}$ & 0.538 & 16.00 & 0 \\
\hline PLA/PHBV/ZnO:Fe0.3 & 2.722 & $<\mathrm{LOD}$ & 0.700 & $<\mathrm{LOD}$ & $<\mathrm{LOD}$ & 0.534 & 9.97 & 0.03 \\
\hline PLA/PHBV/ZnO:Fe0.5 & 1.830 & 0.022 & 0.048 & $<$ LOD & $<$ LOD & 0.727 & 9.95 & 0.05 \\
\hline PLA/PHBV/ZnO:Fe0.7 & 1.009 & 0.026 & 0.038 & $<\mathrm{LOD}$ & $<\mathrm{LOD}$ & 1.143 & 9.93 & 0.07 \\
\hline PLA/PHBV/ZnO:Fe1 & 0.796 & 0.035 & $<\mathrm{LOD}$ & $<$ LOD & $<\mathrm{LOD}$ & 1.423 & 9.90 & 0.10 \\
\hline
\end{tabular}

\subsection{Antimicrobial Evaluation}

In the adherence test, the interaction between the cell surface and the material surface was measured. Thus, fewer P. aeruginosa cells were found attached to the PLA/PHBV/ZnO: Fex samples, as is shown in Table 5. Similar prominent bactericidal activity of polyvinyl alcohol nanofibers was reported with the increase in Fe-doped ZnO nanoparticles (NPs) concentration against Gram-positive Staphylococcus aureus and Gram-negative Escherichia coli bacterial strains [31].

Table 5. Cell number (CFU) at different successive dilution for $\mathrm{ZnO}$ :Fe samples.

\begin{tabular}{cccc}
\hline Sample & $\mathbf{1 : 1 0}$ & $\mathbf{1 : 1 0 0}$ & $\mathbf{1 : 1 0 0 0}$ \\
\hline PLA & 33 & 2 & 0 \\
PLA/PHVB & 10 & 7 & 1 \\
PLA/PHBV/ZnO:Fe0 & 3 & 3 & 0 \\
PLA/PHBV/ZnO:Fe0.3\% & 0 & 0 & 4 \\
PLA/PHBV/ZnO:Fe0.7\% & 7 & 5 & 4 \\
PLA/PHBV/ZnO:Fe1\% & 11 & 8 & 4 \\
\hline
\end{tabular}

The results highlight the importance of using $\mathrm{ZnO}$ :Fex nanoparticles on PLA matrices because all the samples that include this compound in their composition, at different concentrations, showed a lower degree of initial bacterial adhesion to their surface. The materials tested in this study succeed in inhibiting bacterial adhesions.

Generally, the antibacterial effect of ZnO NPs is due to the electronic charge, the small size, and the large surface-volume ratio that allows interactions with bacteria [77], and their capacity to generate reactive oxygen species (ROS), such as hydroxyl radicals $\left(\mathrm{OH}^{-}\right)$, superoxide anion $\left(\mathrm{O}_{2}^{-}\right)$, and perhydroxyl $(\mathrm{OOH})$ [78]. The ROS species are generated by the interaction between electrons or hole generated by the nanoparticles with the water or oxygen from the atmosphere [79]. Fe dopant ions also facilitate ROS generation having a strong toxic effect on the bacteria due to their high reactivity and strong oxidizing properties [80]. By doping, energy levels associated with the dopant are introduced into the $\mathrm{ZnO}$ conduction band which can facilitate the electron-hole separation increasing the probability of ROS generation. At a high doping level, the excessive amounts of doped Fe may act as the recombination centers for the electron-hole pairs by their interaction resulting in low ROS generation and consequently lower antibacterial activity [67].

\subsection{The Evaluation of ROS Generation}

The ROS generated in the presence of PLA/PHBV/ZnO:Fe0.3 nanostructure were monitored by electron spin resonance (ESR) spectroscopy coupled with a spin-trapping technique. The ROS species are involved in the mechanism of antibacterial activity of semiconductors [81]. 
To ensure the origin of these signals, a simulation was performed. The experimental and simulated spectra of PLA/PHBV/ZnO:Fe $0.3 \%$ in DMSO suspension in the presence of DMPO are shown in Figure 9.

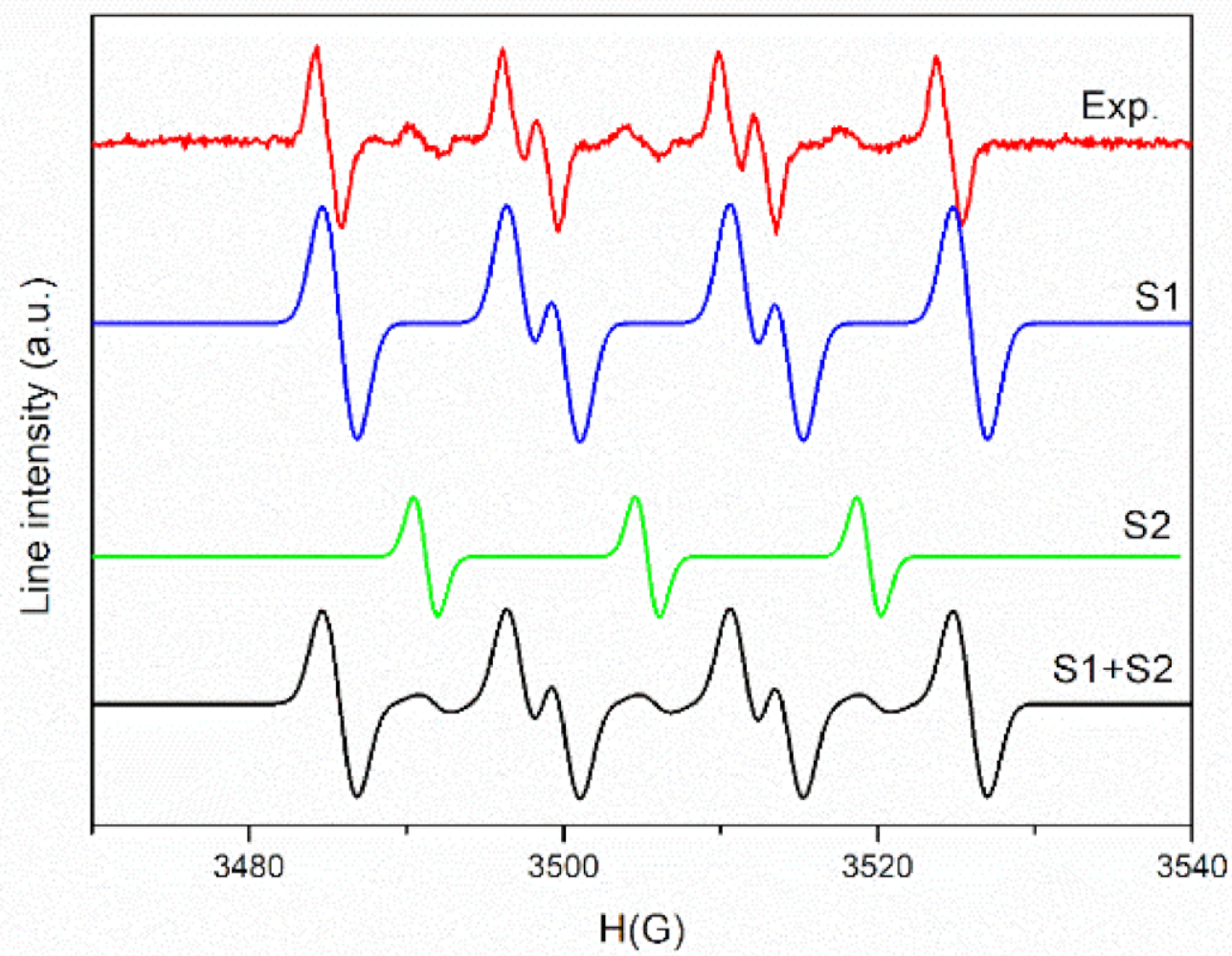

Figure 9. The experimental and simulated spectra of PLA/PHBV/ZnO:Fe0.3\% in DMSO suspension in the presence of DMPO.

As seen in Figure 9, a complex spectrum was obtained, which after simulation reveals the presence of two spin adducts: DMPO-OOH (S1) with hyperfine coupling constants, $\mathrm{a}_{\mathrm{N}}=14.2 \mathrm{G}, \mathrm{a}_{\mathrm{H}}=11.7 \mathrm{G}, \mathrm{a}_{\mathrm{H}}=1 \mathrm{G}$ (relative concentration $90 \%$ ) and a nitroxide-like radical $(\mathrm{S} 2)\left(\mathrm{a}_{\mathrm{N}}=14 \mathrm{G}\right.$, relative concentration $\left.10 \%\right)$. The mechanism of $(\mathrm{OOH})$ radical formation comprises two steps. In the first step, the electrons generated by the interaction of the sample with light (or photogenerated electrons) interact with absorbed $\mathrm{O}_{2}$ and form $\left(\cdot \mathrm{O}_{2}{ }^{-}\right)$radicals. In the second stage, a perhydroxyl $(\mathrm{OOH})$ radical is formed by the $\left(\mathrm{O}_{2}{ }^{-}\right)$ protonation reaction [82]. The presence of nitroxide-like radical is due to the $\mathrm{N}-\mathrm{C}$ bond cleavage followed by the ring-opening of spin trapper (DMPO) [83].

\section{Conclusions}

Coatings of PLA film with PHBV/ZnO:Fex nanosystems were obtained by using the electrospinning process. The process of getting the antimicrobial nanosystems is simple, versatile, and uses reduced amounts of Fe-doped $\mathrm{ZnO}$ nanoparticles. It was conducted at room temperature, without high energy consumption, and without solvents with toxic potential. The samples showed "beads" morphology. Migration in food simulants is within the limits imposed by current legislation. From all investigated samples, the PLA/PHBV/ZnO:Fe0.3 electrospun nanosystem showed a remarkable antimicrobial effect against $P$. aeruginosa (ATCC-27853) bacterial strain due to the generation of a larger amount of perhydroxyl ( $\cdot \mathrm{OOH}$ ) radicals, as evidenced by using the EPR spectroscopy coupled with the spin-trapping method. XPS showed the specific C 1s core-level lines of PLA and PHBV and also the $\mathrm{Zn} 2 \mathrm{p}$ core-level lines for $\mathrm{Zn}^{2+}$ oxidation state specific to $\mathrm{ZnO}$. 


\section{Patents}

M. Stefan, M. Rapa, O. Pana, D. Vodnar, E. Matei, D. G. Barta, A. Popa, D. Toloman, C. Leostean, and S. Macavei, Nanostructures based on PHBV and Fe doped ZnO nanostructures and their obtaining process, Patent Request Nr. A 00322/09.06.2020.

Author Contributions: Conceptualization, M.R. and C.N.; Data curation, P.A.P., D.T., C.L., G.B. and M.S. (Maria Suciu); Formal analysis, D.C.V., M.W., J.S. and D.G.B.; Funding acquisition, C.N. and C.P.; Investigation, M.S. (Maria Stefan), P.A.P., D.T., C.L., G.B., D.C.V., M.W., D.G.B. and M.S. (Maria Suciu); Methodology, J.S., C.P. and E.M.; Project administration, C.P.; Resources, M.S. (Maria Stefan) and E.M.; Validation, M.R.; Visualization, E.M.; Writing—original draft, M.S. (Maria Stefan); Writing-review and editing, M.R. and C.N. All authors have read and agreed to the published version of the manuscript.

Funding: This research was funded by a grant of the Romanian Ministry of Education and Research, CCCDI-UEFISCDI, project number PN-III-P2-2.1-PED-2019-2878, within PNCDI III (BioMatFood), under the Contract No 379PED/2020, Core Program, project number PN 193502 03, and project number PN-III-P1-1.1-MC-2019-1116, within PNCDI III.

Institutional Review Board Statement: Not applicable.

Informed Consent Statement: Not applicable.

Data Availability Statement: The data presented in this study are available upon request from the corresponding author.

Acknowledgments: Thanks are given to Gobierno de Aragón and Fondo Social Europeo for the financial help to GUIA group T53_20R.

Conflicts of Interest: The authors declare no conflict of interest.

\section{References}

1. Fadare, O.; Wan, B.; Guo, L.-H.; Zhao, L. Microplastics from consumer plastic food containers: Are we consuming it? Chemosphere 2020, 253, 126787. [CrossRef]

2. Diaz-Basantes, M.; Conesa, J.; Fullana, A. Microplastics in Honey, Beer, Milk and Refreshments in Ecuador as Emerging Contaminants. Sustainability 2020, 12, 5514. [CrossRef]

3. Kedzierski, M.; Lechat, B.; Sire, O.; Le Maguer, G.; Le Tilly, V.; Bruzaud, S. Microplastic contamination of packaged meat: Occurrence and associated risks. Food Packag. Shelf Life 2020, 24, 100489. [CrossRef]

4. Appendini, P.; Hotchkiss, J.H. Review of antimicrobial food packaging. Innov. Food Sci. Emerg. Technol. 2002, 3, 113-126. [CrossRef]

5. Hanušová, K.; Dobias, J.; Klaudisová, K. Effect of Packaging Films Releasing Antimicrobial Agents on Stability of Food Products. Czech J. Food Sci. 2009, 27, S347-S349. [CrossRef]

6. Darie-Niţă, R.N.; Vasile, C.; Irimia, A.; Lipşa, R.; Râpă, M. Evaluation of some eco-friendly plasticizers for PLA films processing. J. Appl. Polym. Sci. 2016, 133, 43223. [CrossRef]

7. Rapa, M.; Darie-Nita, R.N.; Irimia, A.M.; Sivertsvik, M.; Rosnes, J.T.; Trifoi, A.R.; Vasile, C.; Tanase, E.E.; Gherman, T.; Popa, M.E.; et al. Comparative Analysis of Two Bioplasticizers Used to Modulate the Properties of PLA Biocomposites. Mater. Plast. 2017, 54, 610-615. [CrossRef]

8. D'Amico, D.A.; Montes, M.I.; Manfredi, L.B.; Cyras, V.P. Fully bio-based and biodegradable polylactic acid/poly(3hydroxybutirate) blends: Use of a common plasticizer as performance improvement strategy. Polym. Test. 2016, 49, 22-28. [CrossRef]

9. Manikandan, N.A.; Pakshirajan, K.; Pugazhenthi, G. Preparation and characterization of environmentally safe and highly biodegradable microbial polyhydroxybutyrate (PHB) based graphene nanocomposites for potential food packaging applications. Int. J. Biol. Macromol. 2020, 154, 866-877. [CrossRef] [PubMed]

10. Jayakumar, A.; Prabhu, K.; Shah, L.; Radha, P. Biologically and environmentally benign approach for PHB-silver nanocomposite synthesis and its characterization. Polym. Test. 2020, 81, 106197. [CrossRef]

11. Arrieta, M.P.; Lopez, J.; Hernández, A.; Rayón, E. Ternary PLA-PHB-Limonene blends intended for biodegradable food packaging applications. Eur. Polym. J. 2014, 50, 255-270. [CrossRef]

12. Zhao, X.; Ji, K.; Kurt, K.; Cornish, K.; Vodovotz, Y. Optimal mechanical properties of biodegradable natural rubber-toughened PHBV bioplastics intended for food packaging applications. Food Packag. Shelf Life 2019, 21, 100348. [CrossRef]

13. Requena, R.; Vargas, M.; Chiralt, A. Release kinetics of carvacrol and eugenol from poly(hydroxybutyrate-co-hydroxyvalerate) (PHBV) films for food packaging applications. Eur. Polym. J. 2017, 92, 185-193. [CrossRef] 
14. Costa, M.J.; Pastrana, L.M.; Teixeira, J.A.; Sillankorva, S.M.; Cerqueira, M.A. Characterization of PHBV films loaded with FO1 bacteriophage using polyvinyl alcohol-based nanofibers and coatings: A comparative study. Innov. Food Sci. Emerg. Technol. 2021, 69, 102646. [CrossRef]

15. Arrieta, M.P.; Samper, M.D.; Aldas, M.; López, J. On the Use of PLA-PHB Blends for Sustainable Food Packaging Applications. Materials 2017, 10, 1008. [CrossRef] [PubMed]

16. Dasan, Y.K.; Bhat, A.H.; Ahmad, F. Polymer blend of PLA/PHBV based bionanocomposites reinforced with nanocrystalline cellulose for potential application as packaging material. Carbohydr. Polym. 2017, 157, 1323-1332. [CrossRef]

17. He, Y.; Hu, Z.; Ren, M.; Ding, C.; Chen, P.; Gu, Q.; Wu, Q. Evaluation of PHBHHx and PHBV/PLA fibers used as medical sutures. J. Mater. Sci. Mater. Electron. 2013, 25, 561-571. [CrossRef]

18. Xu, Z.; Chai, X. Effect of weight ratios of PHBV/PLA polymer blends on nitrate removal efficiency and microbial community during solid-phase denitrification. Int. Biodeterior. Biodegrad. 2017, 116, 175-183. [CrossRef]

19. Gavril, G.-L.; Wrona, M.; Bertella, A.; Świeca, M.; Râpă, M.; Salafranca, J.; Nerín, C. Influence of medicinal and aromatic plants into risk assessment of a new bioactive packaging based on polylactic acid (PLA). Food Chem. Toxicol. 2019, 132, 110662. [CrossRef]

20. Kumar, S.; Basumatary, I.B.; Sudhani, H.P.; Bajpai, V.K.; Chen, L.; Shukla, S.; Mukherjee, A. Plant extract mediated silver nanoparticles and their applications as antimicrobials and in sustainable food packaging: A state-of-the-art review. Trends Food Sci. Technol. 2021, 112, 651-666. [CrossRef]

21. Liu, Y.; Sameen, D.E.; Ahmed, S.; Dai, J.; Qin, W. Antimicrobial peptides and their application in food packaging. Trends Food Sci. Technol. 2021, 112, 471-483. [CrossRef]

22. Bahmid, N.A.; Dekker, M.; Fogliano, V.; Heising, J. Modelling the effect of food composition on antimicrobial compound absorption and degradation in an active packaging. J. Food Eng. 2021, 300, 110539. [CrossRef]

23. Saedi, S.; Shokri, M.; Kim, J.T.; Shin, G.H. Semi-transparent regenerated cellulose/ZnONP nanocomposite film as a potential antimicrobial food packaging material. J. Food Eng. 2021, 307, 110665. [CrossRef]

24. Parida, D.; Simonetti, P.; Frison, R.; Bülbül, E.; Altenried, S.; Arroyo, Y.; Balogh-Michels, Z.; Caseri, W.; Ren, Q.; Hufenus, R.; et al. Polymer-assisted in-situ thermal reduction of silver precursors: A solventless route for silver nanoparticles-polymer composites. Chem. Eng. J. 2020, 389, 123983. [CrossRef]

25. Kongkaoroptham, P.; Piroonpan, T.; Pasanphan, W. Chitosan nanoparticles based on their derivatives as antioxidant and antibacterial additives for active bioplastic packaging. Carbohydr. Polym. 2021, 257, 117610. [CrossRef]

26. Silveira, V.A.I.; Marim, B.M.; Hipólito, A.; Gonçalves, M.C.; Mali, S.; Kobayashi, R.K.T.; Celligoi, M.A.P.C. Characterization and antimicrobial properties of bioactive packaging films based on polylactic acid-sophorolipid for the control of foodborne pathogens. Food Packag. Shelf Life 2020, 26, 100591. [CrossRef]

27. Bower, C.K.; McGuire, J.; Daeschel, M.A. The adhesion and detachment of bacteria and spores on food-contact surfaces. Trends Food Sci. Technol. 1996, 7, 152-157. [CrossRef]

28. Commission Regulation (EU) No. 10/2011 of 14 January 2011 on Plastic Materials and Articles Intended to Come into Contact with Food. Available online: https://eur-lex.europa.eu/legal-content/EN/TXT/PDF/?uri=CELEX:32011R0010\&from=HR (accessed on 27 April 2021).

29. Dehghani, S.; Peighambardoust, S.H.; Peighambardoust, S.J.; Hosseini, S.V.; Regenstein, J.M. Improved mechanical and antibacterial properties of active LDPE films prepared with combination of $\mathrm{Ag}$, $\mathrm{ZnO}$ and $\mathrm{CuO}$ nanoparticles. Food Packag. Shelf Life 2019, 22, 100391. [CrossRef]

30. Zare, M.; Namratha, K.; Iyas, S.; Hezam, A.; Mathur, S.; Byrappa, K. Smart Fortified PHBV-CS Biopolymer with ZnO-Ag Nanocomposites for Enhanced Shelf Life of Food Packaging. ACS Appl. Mat. Interfaces 2019, 11, 48309-48320. [CrossRef] [PubMed]

31. Sekar, A.D.; Kumar, V.; Muthukumar, H.; Gopinath, P.; Matheswaran, M. Electrospinning of Fe-doped ZnO nanoparticles incorporated polyvinyl alcohol nanofibers for its antibacterial treatment and cytotoxic studies. Eur. Polym. J. 2019, 118, 27-35. [CrossRef]

32. Syame, M.S.; Mohamed, W.; Mahmoud, R.K.; Omara, S.T. Synthesis of Copper-Chitosan Nanocomposites and its Application in Treatment of Local Pathogenic Isolates Bacteria. Orient. J. Chem. 2017, 33, 2959-2969. [CrossRef]

33. Noshirvani, N.; Ghanbarzadeh, B.; Mokarram, R.R.; Hashemi, M. Novel active packaging based on carboxymethyl cellu-losechitosan-ZnO NPs nanocomposite for increasing the shelf life of bread. Food Packag. Shelf Life 2017, 11, 106-114. [CrossRef]

34. Vera, P.; Echegoyen, Y.; Canellas, E.; Nerín, C.; Palomo, M.; Madrid, Y.; Cámara, C. Nano selenium as antioxidant agent in a multilayer food packaging material. Anal. Bioanal. Chem. 2016, 408, 6659-6670. [CrossRef] [PubMed]

35. Vera, P.; Canellas, E.; Nerín, C. New Antioxidant Multilayer Packaging with Nanoselenium to Enhance the Shelf-Life of Market Food Products. Nanomaterials 2018, 8, 837. [CrossRef] [PubMed]

36. Echegoyen, Y.; Nerín, C. Nanoparticle release from nano-silver antimicrobial food containers. Food Chem. Toxicol. 2013, 62, 16-22. [CrossRef]

37. Echegoyen, Y.; Rodríguez, S.; Nerín, C. Nanoclay migration from food packaging materials. Food Addit. Contam. Part A 2016, 33, 530-539. [CrossRef]

38. Souza, V.G.L.; Fernando, A.L. Nanoparticles in food packaging: Biodegradability and potential migration to food-A review. Food Packag. Shelf Life 2016, 8, 63-70. [CrossRef] 
39. Habba, Y.G.; Capochichi-Gnambodoe, M.; Leprince-Wang, Y. Enhanced Photocatalytic Activity of Iron-Doped ZnO Nanowires for Water Purification. Appl. Sci. 2017, 7, 1185. [CrossRef]

40. Sun, L.; Han, J.; Liu, Z.; Wei, S.; Su, X.; Zhang, G. The facile fabrication of wound compatible anti-microbial nanoparticles encapsulated Collagenous Chitosan matrices for effective inhibition of poly-microbial infections and wound repairing in burn injury care: Exhaustive in vivo evaluations. J. Photochem. Photobiol. B Biol. 2019, 197, 111539. [CrossRef]

41. Păunica-Panea, G.; Ficai, A.; Marin, M.M.; Marin, Ștefania; Albu, M.G.; Constantin, V.D.; Dinu-Pîrvu, C.; Vuluga, Z.; Corobea, M.C.; Ghica, M.V. New Collagen-Dextran-Zinc Oxide Composites for Wound Dressing. J. Nanomater. 2016, 2016, 1-7. [CrossRef]

42. Naphade, R.; Jog, J. Electrospinning of PHBV/ZnO membranes: Structure and properties. Fibers Polym. 2012, 13, 692-697. [CrossRef]

43. Rivera-Briso, A.L.; Serrano-Aroca, Á. Poly(3-Hydroxybutyrate-co-3-Hydroxyvalerate): Enhancement Strategies for Advanced Applications. Polymers 2018, 10, 732. [CrossRef] [PubMed]

44. Díez-Pascual, A.M.; Díez-Vicente, A.L. ZnO-Reinforced Poly(3-hydroxybutyrate-co-3-hydroxyvalerate) Bionanocomposites with Antimicrobial Function for Food Packaging. ACS Appl. Mater. Interfaces 2014, 6, 9822-9834. [CrossRef]

45. Yadav, S.; Mehrotra, G.K.; Dutta, P.K. Chitosan based ZnO nanoparticles loaded gallic-acid films for active food packaging. Food Chem. 2021, 334, 127605. [CrossRef]

46. Li, W.; Li, L.; Cao, Y.; Lan, T.; Chen, H.; Qin, Y. Effects of PLA Film Incorporated with ZnO Nanoparticle on the Quality Attributes of Fresh-Cut Apple. Nanomaterials 2017, 7, 207. [CrossRef]

47. Liu, Y.; Li, Y.; Deng, L.; Zou, L.; Feng, F.; Zhang, H. Hydrophobic Ethylcellulose/Gelatin Nanofibers Containing Zinc Oxide Nanoparticles for Antimicrobial Packaging. J. Agric. Food Chem. 2018, 66, 9498-9506. [CrossRef] [PubMed]

48. Abbas, M.; Buntinx, M.; Deferme, W.; Peeters, R. (Bio)polymer/ZnO Nanocomposites for Packaging Applications: A Review of Gas Barrier and Mechanical Properties. Nanomaterials 2019, 9, 1494. [CrossRef] [PubMed]

49. Sadhasivam, S.; Shanmugam, M.; Umamaheswaran, P.D.; Venkattappan, A.; Shanmugam, A. Zinc Oxide Nanoparticles: Green Synthesis and Biomedical Applications. J. Clust. Sci. 2020, 10, 1-15. [CrossRef]

50. Kołodziejczak-Radzimska, A.; Jesionowski, T. Zinc Oxide-From Synthesis to Application: A Review. Materials 2014, 7, $2833-2881$. [CrossRef] [PubMed]

51. Ong, C.B.; Ng, L.Y.; Mohammad, A.W. A review of ZnO nanoparticles as solar photocatalysts: Synthesis, mechanisms and applications. Renew. Sustain. Energy Rev. 2018, 81, 536-551. [CrossRef]

52. Hameed, A.S.H.; Karthikeyan, C.; Sasikumar, S.; Senthil Kumar, V.; Kumaresan, S.; Ravi, G. Impact of Alkaline Metal Ions Mg2+, $\mathrm{Ca} 2+, \mathrm{Sr} 2+$ and $\mathrm{Ba} 2+$ on the Structural, Optical, Thermal and Antibacterial Properties of ZnO Nanoparticles Pre-pared by the Co-Precipitation Method. J. Mater. Chem. B 2013, 1, 5950-5962. [CrossRef]

53. Kumar, V.R.; Wariar, P.R.S.; Prasad, V.S.; Koshy, J. A novel approach for the synthesis of nanocrystalline zinc oxide powders by room temperature co-precipitation method. Mater. Lett. 2011, 65, 2059-2061. [CrossRef]

54. Fang, Y.; Li, Z.; Xu, S.; Han, D.; Lu, D. Optical properties and photocatalytic activities of spherical ZnO and flower-like ZnO structures synthesized by facile hydrothermal method. J. Alloys Compd. 2013, 575, 359-363. [CrossRef]

55. Jiao, S.; Zhang, K.; Bai, S.; Li, H.; Gao, S.; Li, H. Controlled morphology evolution of ZnO nanostructures in the electrochem-ical deposition: From the point of view of chloride ions. Electrochim. Acta 2013, 111, 64-70. [CrossRef]

56. Banerjee, P.; Chakrabarti, S.; Maitra, S.; Dutta, B.K. Zinc oxide nano-particles-Sonochemical synthesis, characterization and application for photo-remediation of heavy metal. Ultrason. Sonochem. 2012, 19, 85-93. [CrossRef]

57. Ba-Abbad, M.M.; Kadhum, A.A.H.; Mohamad, A.B.; Takriff, M.S.; Sopian, K. Optimizationof process parameters using D-optimal design for synthesis of ZnO nanoparticlesvia sol-gel technique. J. Ind. Eng. Chem. 2013, 19, 99-105. [CrossRef]

58. Suwanboon, S.; Amornpitoksuk, P.; Sukolrat, A. Dependence of optical properties on doping metal, crystallite size and defect concentration of M-doped $\mathrm{ZnO}$ nanopowders ( $\mathrm{M}=\mathrm{Al}, \mathrm{Mg}$, Ti). Ceram. Int. 2011, 37, 1359-1365. [CrossRef]

59. Li, M.; Xu, J.; Chen, X.; Zhang, X.; Wu, Y.; Li, P.; Niu, X.; Luo, C.; Li, L. Structural and optical properties of cobalt doped ZnO nanocrystals. Superlattices Microstruct. 2012, 52, 824-833. [CrossRef]

60. Weidermaier, K.; Carruthers, E.; Curry, A.; Kuroda, M.; Fallows, E.; Thomas, J.; Sherman, D.; Muldoon, M. Real-time patho-gen monitoring during enrichment: A novel nanotechnology-based approach to food safety testing. Int. J. Food Microbiol. 2015, 198, 19-27. [CrossRef]

61. Mishra, P.K.; Mishra, H.; Ekielski, A.; Talegaonkar, S.; Vaidya, B. Zinc oxide nanoparticles: A promising nanomaterial for biomedical applications. Drug Discov. Today 2017, 22, 1825-1834. [CrossRef]

62. Pantani, R.; Gorrasi, G.; Vigliotta, G.; Murariu, M.; Dubois, P. PLA-ZnO nanocomposite films: Water vapor barrier properties and specific end-use characteristics. Eur. Polym. J. 2013, 49, 3471-3482. [CrossRef]

63. Vasile, C.; Rapa, M.; Stefan, M.; Stan, M.; Macavei, S.; Darie-Nita, R.N.; Barbu-Tudoran, L.; Vodnar, D.C.; Popa, E.E.; Stefan, R.; et al. New PLA/ZnO:Cu/Ag bionanocomposites for food packaging. Express Polym. Lett. 2017, 11, 531-544. [CrossRef]

64. Anžlovar, A.; Kržan, A.; Žagar, E. Degradation of PLA/ZnO and PHBV/ZnO composites prepared by melt processing. Arab. J. Chem. 2018, 11, 343-352. [CrossRef]

65. Jayaramudu, J.; Das, K.; Sonakshi, M.; Reddy, G.S.M.; Aderibigbe, B.; Sadiku, R.; Ray, S.S. Structure and properties of highly toughened biodegradable polylactide/ZnO biocomposite films. Int. J. Biol. Macromol. 2014, 64, 428-434. [CrossRef]

66. Petropoulou, A.; Christodoulou, K.; Polydorou, C.; Krasia-Christoforou, T.; Riziotis, C. Cost-Effective Polymethacrylate-Based Electrospun Fluorescent Fibers toward Ammonia Sensing. Macromol. Mater. Eng. 2017, 302, 1600453. [CrossRef] 
67. Toloman, D.; Mesaros, A.; Popa, A.; Silipas, T.D.; Neamtu, S.; Katona, G. V-doped ZnO particles: Synthesis, structural, optical and photocatalytic properties. J. Mater. Sci. Mater. Electron. 2016, 27, 5691-5698. [CrossRef]

68. Tanner, J.; Vallittu, P.K.; Söderling, E. Adherence of Streptococcus mutans to an E-glass fiber-reinforced composite and conventional restorative materials used in prosthetic dentistry. J. Biomed. Mater. Res. 2000, 49, 250-256. [CrossRef]

69. Iqbal, T.; Khan, M.; Mahmood, H. Facile synthesis of ZnO nanosheets: Structural, antibacterial and photocatalytic studies. Mater. Lett. 2018, 224, 59-63. [CrossRef]

70. Pascuta, P.; Vladescu, A.; Borodi, G.; Culea, E.; Tetean, R. Structural and magnetic properties of zinc ferrite incorporated in amorphous matrix. Ceram. Int. 2011, 37, 3343-3349. [CrossRef]

71. BIOVIA, D.S. Materials Studio v8.0.0.843; Dassault Systèmes: San Diego, CA, USA, 2014.

72. Iglesias Montes, M.L.; Luzi, F.; Dominici, F.; Torre, L.; Cyras, V.P.; Manfredi, L.B.; Puglia, D. Design and Characterization of PLA Bilayer Films Containing Lignin and Cellulose Nanostructures in Combination With Umbelliferone as Active Ingredient. Front. Chem. 2019, 7, 157. [CrossRef]

73. Yu, H.-Y.; Yao, J.-M. Reinforcing properties of bacterial polyester with different cellulose nanocrystals via modulating hydro-gen bonds. Compos. Sci. Technol. 2016, 136, 53-60. [CrossRef]

74. Zembouai, I.; Kaci, M.; Bruzaud, S.; Benhamida, A.; Corre, Y.-M.; Grohens, Y. A study of morphological, thermal, rheological and barrier properties of Poly(3-hydroxybutyrate-Co-3-Hydroxyvalerate)/polylactide blends prepared by melt mixing. Polym. Test. 2013, 32, 842-851. [CrossRef]

75. Patel, D.I.; Noack, S.; Vacogne, C.D.; Schlaad, H.; Bahr, S.; Dietrich, P.; Meyer, M.; Thißen, A.; Linford, M.R. Poly(l-lactic acid), by near-ambient pressure XPS. Surf. Sci. Spectra 2019, 26, 024004. [CrossRef]

76. Bumbudsanpharoke, N.; Choi, J.; Park, H.J.; Ko, S. Zinc migration and its effect on the functionality of a low density polyethyleneZnO nanocomposite film. Food Packag. Shelf Life 2019, 20, 100301. [CrossRef]

77. Babu, L.K.; Sarala, E.; Audiseshaiah, O.; Reddy, K.M.; Reddy, R.Y.V. Synthesis, characterisation of nanocrystalline ZnO via two different chemical methods and its antibacterial activity. Surf. Interfaces 2019, 16, 93-100. [CrossRef]

78. da Silva, B.L.; Caetano, B.L.; Chiari-Andréo, B.G.; Pietro, R.C.L.R.; Chiavacci, L.A. Increased antibacterial activity of ZnO nanoparticles: Influence of size and surface modification. Colloids Surf. B Biointerfaces 2019, 177, 440-447. [CrossRef] [PubMed]

79. Lakshmi Prasanna, V.; Vijayaraghavan, R. Insight into the Mechanism of Antibacterial Activity of ZnO: Surface Defects Mediated Reactive Oxygen Species Even in the Dark. Langmuir 2015, 31, 9155-9162. [CrossRef]

80. Sirelkhatim, A.; Mahmud, S.; Seeni, A.; Kaus, N.H.M.; Ann, L.C.; Bakhori, S.K.M.; Hasan, H.; Mohamad, D. Review on Zinc Oxide Nanoparticles: Antibacterial Activity and Toxicity Mechanism. Nano-Micro Lett. 2015, 7, 219-242. [CrossRef]

81. He, W.; Kim, H.-K.; Wamer, W.G.; Melka, D.; Callahan, J.H.; Yin, J.-J. Photogenerated Charge Carriers and Reactive Oxygen Species in ZnO/Au Hybrid Nanostructures with Enhanced Photocatalytic and Antibacterial Activity. J. Am. Chem. Soc. 2014, 136, 750-757. [CrossRef] [PubMed]

82. Alyani, S.J.; Pirbazari, A.E.; Khalilsaraei, F.E.; Kolur, N.A.; Gilani, N. Growing Co-doped TiO2 nanosheets on reduced graphene oxide for efficient photocatalytic removal of tetracycline antibiotic from aqueous solution and modeling the process by artificial neural network. J. Alloys Compd. 2019, 799, 169-182. [CrossRef]

83. Diaz-Uribe, C.E.; Daza, M.C.; Martínez, F.; Páez-Mozo, E.A.; Guedes, C.; Di Mauro, E. Visible light superoxide radical anion generation by tetra(4-carboxyphenyl)porphyrin/TiO2: EPR characterization. J. Photochem. Photobiol. A Chem. 2010, 215, 172-178. [CrossRef] 